\title{
20. A STUDY OF ORGANIC MATTER FROM DEEP OCEANIC BORE HOLES, DEEP SEA DRILLING PROJECT SITES 415 AND 416, IN THE MOROCCAN BASIN
}

\author{
E. M. Galimov, L. A. Kodina, V. G. Shirinsky, T. V. Drozdova, V. N. Generalova, \\ M. P. Bogachova, V. A. Chinyonov, and L. A. Bannikova, V. I. Vernadsky Institute of Geochemistry \\ and Analytical Chemistry, Academy of Sciences of the U.S.S.R., Moscow
}

\section{INTRODUCTION}

On DSDP Leg 50, D/V Glomar Challenger drilled two deep bore holes, 415A and 416A, in the Moroccan Basin of the Atlantic Ocean, at the foot of the West African continental slope, approximately $150 \mathrm{~km}$ from the coast of Morocco. Hole 415A was stopped at a sub-bottom depth of 1079.5 meters, in upper-Albian deposits. Hole $416 \mathrm{~A}$ reached a depth of 1624 meters and penetrated Upper Jurassic deposits.

A characteristic feature of the investigated sections is the diversity of sources of organic matter in the sediments. Sedimentological analysis reveals both pelagic and continental sediments in the sections. The continental sediments often contain structurally intact residues of higher plants. In some samples, amber grains were found. One of our tasks was to estimate the relative contributions of marine and continental organic material in the sediments and to ascertain the distinguishing features of geochemical evolution of mixed-origin organic matter, which is evidently characteristic of oceanic basins of continental peripheries.

The considerable thickness of the penetrated sediments gave grounds for the hope of discerning certain transformations of organic matter with depth. The main stage of oil generation is known to begin in continental sedimentary profiles at depths of about 1500 meters. It was considered extremely interesting to estimate the state of organic matter at similar depths in the profile of oceanic sediments, since this is directly relevant to the estimation of prospects of oil formation in oceanic deposits.

The methods applied in our organic matter studies are indicated in Figure 1. Individual components (hydrocarbons, resins, asphaltenes, humic acids) of organic matter were identified, and their concentration determined; the concentrations of bitumen and total organic carbon in the sediment were also determined. Bitumen and its fractions were studied by spectral methods in the UV, visible, and IR ranges, as well as by the ESR method. For all the isolated organic-matter components, the isotopic composition of carbon was determined. The hydrocarbon fraction of the extract was investigated by gas-liquid chromatography to assess the content of individual $n$-alkanes and isoprenoids. An attempt was made to analyze bitumen by ${ }^{13} \mathrm{C}$ NMRspectroscopy, using the Brucker HX-270 instrument. The quantity of matter, however, proved to be insufficient to obtain informative spectra.

\section{SAMPLING}

Samples for organic geochemical studies were taken on shipboard immediately after the core had been raised to the surface and the core sampler opened. Observations of the process of core sampling in the course of drilling showed that, with the presently applied technology, there is a serious danger of the core being contaminated by lubricants. The steel cable used to raise the core barrel is usually covered with a thick coat of lubricant. This lubricant pollutes the inner walls of the drill pipes and not infrequently penetrates into the plastic liner with the core. It is clear that the slightest presence of a lubricant in the core completely invalidates any possibility of investigations in organic geochemistry. So as to reduce this danger to a minimum, the sections from which the samples were taken were subjected to thorough visual control on shipboard. Whenever possible, the portion of the core directly adjoining the plastic container was discarded, especially in the case of loose sediments. In the laboratory, the core was subjected to total mechanical primary treatment. The surface layer of every individual piece of the core was removed. This work seems to have been the most arduous part of investigations, the results of which are presented in this paper.

\section{EXPERIMENTAL PROCEDURE}

\section{Pretreatment}

The samples taken on shipboard were packed into air-tight plastic packets and stored in a frozen state. The packets were opened and the samples unfrozen just before the work with them started. To eliminate the possibility of contamination, the surface layers of all pieces were then removed. It should be noted that in the course of treatment no visible traces of contamination were encountered in the samples studied. The only exception is in Section 416A-2-2, on the surface of one of the pieces of which some lubricant was found.

After the removal of the surface layer, samples were dried in a vacuum dryer at a temperature of 45 to $50^{\circ} \mathrm{C}$, ground in an agate mortar, and sifted through a 60mesh sieve.

\section{Separation of Organic-Matter Components from the Sediment}

Figure 2 shows the scheme for separation and fractionation of organic matter. 


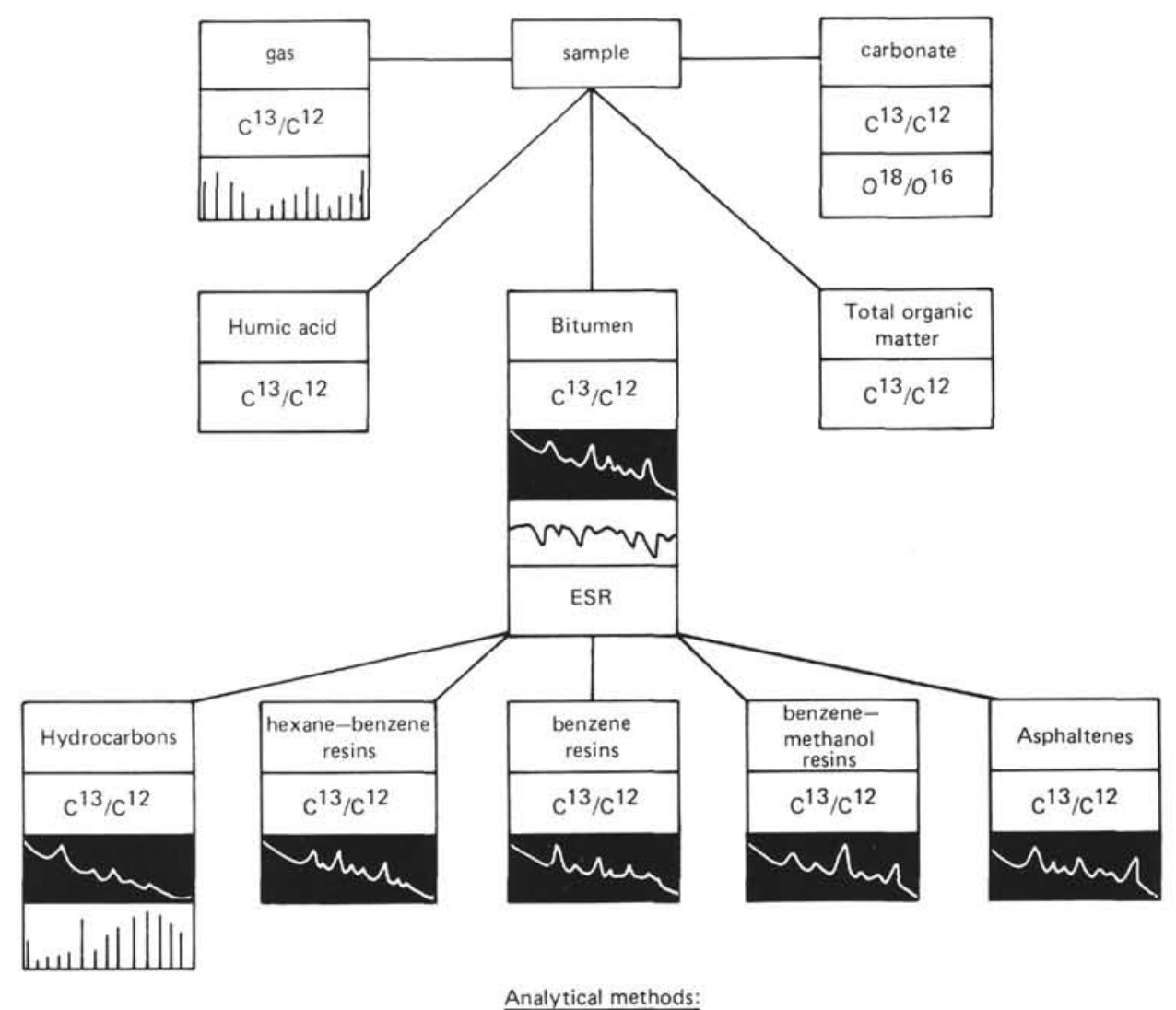

\begin{tabular}{|c|c|}
\hline$c^{13} / c^{12}$ & $\begin{array}{l}\text { mass-spectrometric determination } \\
\text { of isotope composition }\end{array}$ \\
\hline $0^{18} / 0^{16}$ & \\
\hline
\end{tabular}

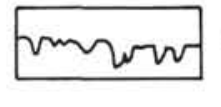

IR-spectroscopy
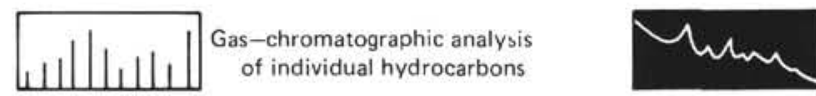

Visible-light spectroscopy

ESR

Electron-spin-resonance spectroscopy

Figure 1. Scheme of investigation of the samples from DSDP Sites 415 and 416 in the Carbon Geochemistry Laboratory of the Vernadsky Institute of Geochemistry and Analytical Chemistry, Academy of Sciences of the U.S.S.R.

A portion of a sample (1-2 g) was treated with hydrochloric acid while being heated, then thoroughly washed with water. Total organic carbon and its isotopic composition were determined in this portion.

The bulk of the ground sample $(100-500 \mathrm{~g})$ was subjected to extraction to isolate the bitumen. Extraction was conducted in a Soxhlet apparatus with a benzenemethanol (9:1) mixture for 48 hours. All the solvents used in this work were purified by distillation, and the paper for cartridges and filters was pre-extracted with a benzene-methanol (1:1) mixture. The benzene-methanol extract was filtered and thickened in a rotary evaporator, with practically complete removal of the solvent. The bitumen residue was washed several times with distilled water to a negative reaction toward chlorine to remove the soluble salts, then dried at 45 to $50^{\circ} \mathrm{C}$.
Bitumen was freed of elemental sulfur with activitated copper. For this purpose, freshly prepared copper was added to the bitumen solution in a minimum volume of benzene-methanol $(9: 1)$; the mixture was shaken for for 2 to 3 hours, after which the bitumen solution was filtered through a layer of paper pulp, the filter being thoroughly washed with small amounts of solvent. The filtrate was thickened to dryness and dried in a vacuum desiccator to a constant weight.

The bitumen, freed of soluble salts and elemental sulfur, was dissolved in a minimum volume of benzene $(2 \mathrm{ml})$, and excess pentane $(100 \mathrm{ml})$ was added to precipitate asphaltenes. Asphaltenes were separated by filtering through a No. 3 glass filter; the precipitate was removed from the filter by dissolving it in chloroform. The pentane solution was evaporated to dryness, and 


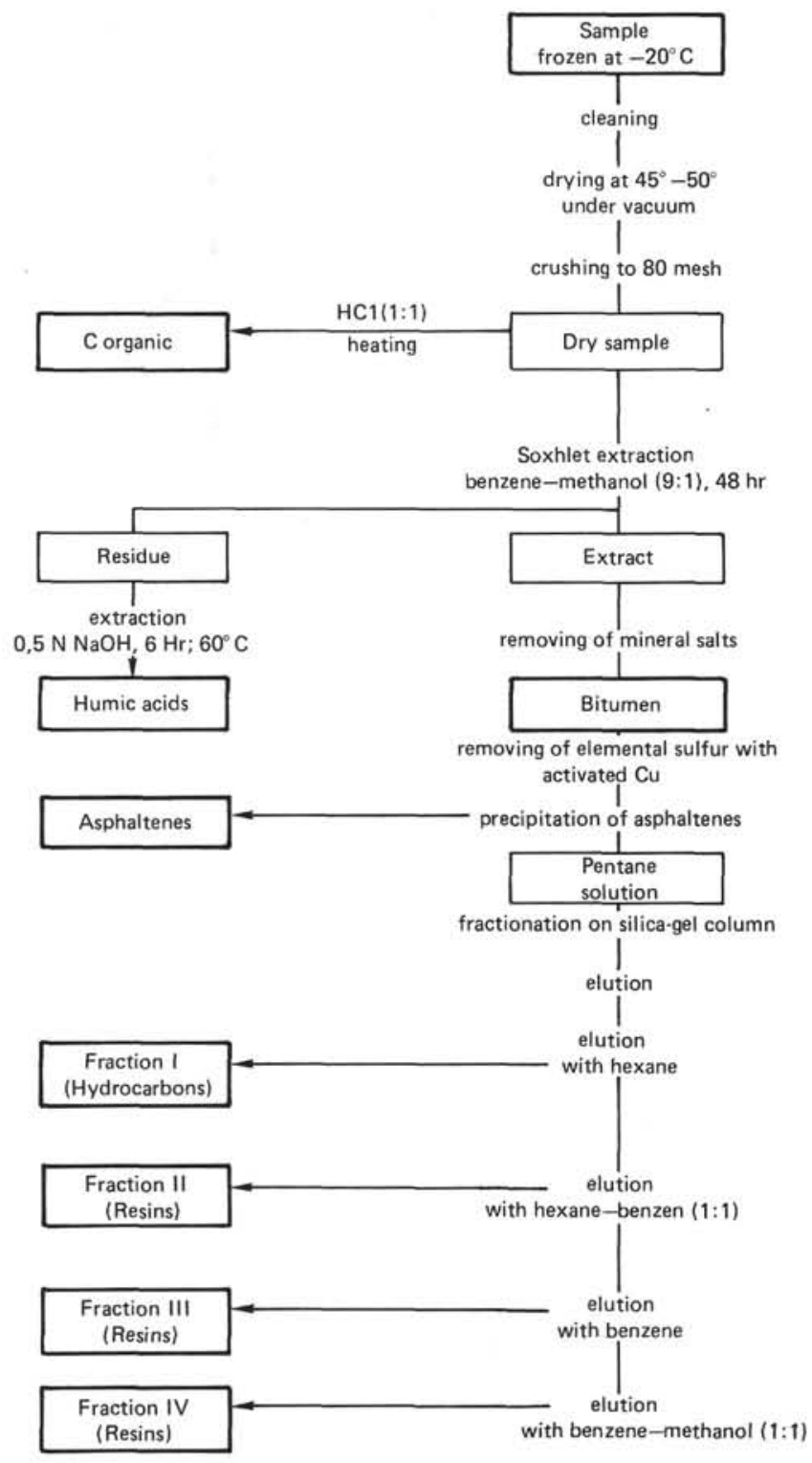

Figure 2. Flow sheet for separation and fractionation of the organic matter of samples from Sites 415 and 416.

the residue was dissolved in 1 to $2 \mathrm{ml}$ of hexane and fractionated on a silica-gel column.

The silica gel used in this work was of the ASK brand, with a grain size of 0.25 to $0.14 \mathrm{~mm}$ (60-100 mesh), repeatedly pre-washed with concentrated $\mathrm{HCl}$, thoroughly washed with water, and activated for 12 hours at $120^{\circ} \mathrm{C}$. Column diameter was 5 or $10 \mathrm{~mm}$; the weight ratio of silica gel to sample was $35: 1$. The sample, in the form of a hexane solution, was applied on the top of the silica-gel column, which had been moistened with hexane, and 2 hours later eluted with solvents of increasing polarity, in the following order: hexane, hexane-benzene (1:1), benzene, benzene-methanol (1:1). The fraction eluted from the column by hexane is enriched in light, non-polar components; aliphatic and aromatic hydrocarbons have been identified in it. This fraction is first practically colorless; after the solvent has been distilled off it is light yellow, pink, or sometimes light brown. This fraction can be regarded as the hydrocarbon fraction. The fractions eluted by solvents of higher polarity are, according to conventional terminology, resins. The fraction eluted from the column by the hexane-benzene (1:1) mixture represents low-polarity resins. These are first light yellow, or sometimes pink, the color evidently caused by nickel porphyrins. With thickening, the color changes to intense brown. Benzene resins constitute a fraction transitional from the lowpolarity fractions to the fraction of alcohol-benzene resins; they are dark and are richest in heteroatoms.

After extraction of bitumens, the sediment was treated with a $0.5 \mathrm{~N}$ solution of $\mathrm{NaOH}$ at $60^{\circ} \mathrm{C}$ for 6 hours to extract humic acids. The filtrate was acidified to a $p \mathrm{H}$ of 1 to 2 . The precipitate of humic acids was reprecipitated under the alternating action of $0.5 \mathrm{~N} \mathrm{NaOH}$ and $6 \mathrm{~N}$ $\mathrm{HCl}$, washed with distilled water, and purified by dialysis. If the alkaline solution was yellow after the separation of humic acids, it was dialyzed to isolate fulvic acids.

\section{Gas-Liquid Chromatography}

The hexane fraction, obtained after the column chromatography of bitumen, was evaporated to a volume of approximately $0.5 \mathrm{ml}$ and inserted into the chromatograph evaporator. The aliphatic hydrocarbons were analyzed on the TSVET-136 gas chromatograph, with a flame-ionization detector. A copper capillary column, 45 meters long and $0.25 \mathrm{~mm}$ in diameter, was used. "Apiezon L" served as the standard. Hydrogen was used as the carrier gas. Temperature was raised from 100 to $320^{\circ} \mathrm{C}$ at the rate of $3 \mathrm{deg} / \mathrm{min}$. The hydrocarbons were identified by comparing their retention time with that of the hydrocarbons of the standard.

\section{Isotopic Analysis of Carbon}

Carbon in the investigated organic-matter components was oxidized to $\mathrm{CO}_{2}$ in an oxygen flow in a closed circulation system containing a reactor with copper oxide heated to $800^{\circ} \mathrm{C}$. Whenever necessary, removal of $\mathrm{SO}_{2}$ and $\mathrm{N}_{2} \mathrm{O}$ was conducted in furnaces with $\mathrm{MnO}$ and refined copper.

The isotopic composition of carbon was measured on the Varian MAT-230 mass spectrometer. The instrument error did not exceed \pm 0.05 per mill. Reproducibility of experimental results, including the full cycle of sample preparation, was within \pm 0.3 to 0.5 per mill.

Results of analyses are given as $\delta^{13} \mathrm{C}$, which represent the deviation, in parts per thousand, of ${ }^{13} \mathrm{C} /{ }^{12} \mathrm{C}$ in the sample studied from ${ }^{13} \mathrm{C} /{ }^{12} \mathrm{C}$ of the PDB standard, for which ${ }^{13} \mathrm{C} /{ }^{12} \mathrm{C}$ is taken as 0.0112372 .

\section{UV- and Visible-Light Spectroscopy}

Absorption spectra were recorded on an SF-8 recording spectrophotometer in the visible region from 320 to $700 \mathrm{~nm}$. The spectra of bitumen fractions were taken in the solvents used to elute them from the column during bitumen fractionation. The total-bitumen spectrum was taken in a benzene-methanol (1:1) solution. 


\section{IR-Spectroscopy}

Spectra in the infrared region were taken on a UR-20 spectrometer in the range 3800 to $400 \mathrm{~cm}^{-1}$. The were applied in the form of thin films on a $\mathrm{KBr}$ plate. The relative intensity of lines was determined with respect to the intensity of the $1460-\mathrm{cm}^{-1}$ band.

\section{ESR-Spectroscopy}

The electron-spin-resonance spectra of bitumens were recorded on the ERS-220 (CWG AW DDR) and EPR-20 (IKhF AN SSSR) spectrometers, with an operating frequency of $10 \mathrm{GHz}$ and magnetic-field-modulation frequency of $100 \mathrm{KHz}$. The SHF power $(5 \mathrm{Mw})$ and the modulation amplitude $(5 \mathrm{Er})$ ensured the recording of spectra without distortions. Bitumen dissolved in chloroform (concentration about $10-20 \%$ ) was placed in a quartz tube $0.3 \mathrm{~cm}$ in diameter and its spectrum was recorded at a temperature of $77^{\circ} \mathrm{C}$.

\section{RESULTS}

\section{The Content of Organic Matter and its Components}

\section{Total Organic Matter}

The content of organic carbon in the profile of Hole $415 \mathrm{~A}$ varies from 0.10 to 1.14 per cent. In the lower (Mesozoic) part of the section, organic-carbon content in the sediments is markedly higher $(0.29-1.14 \%)$ than in the upper (Cenozoic) part of the section $(0.12-$ $0.20 \%$; Table 1 ).

In the profile of Hole 416A, organic-carbon content varies from 0.05 to 0.75 per cent and does not systematically vary with depth or stratigraphic position (Table $2)$. The minimum organic-carbon content $(0.05-0.1 \%)$ is found in the lower part portion of the section. On the average, organic-carbon content is approximately 0.4 per cent, which is close to the clark value for sedimentary rocks of the crust.

\section{Bitumen}

At Site 415 , bitumen content varies from 35 to 850 $\mathrm{ppm}$. Bitumen concentrations are proportional to organic-carbon content. The bitumen coefficient (ratio of bitumen and total organic carbon) stays at approximately the same level all through the profile.

In the profile of Hole $416 \mathrm{~A}$, bitumen content varies within approximately the same limits $(21-590 \mathrm{ppm})$. The bitumen coefficient does not tend to increase with depth. Even at depths of about 1500 meters, the bitumen coefficient does not exceed the average value for the section $(4-5 \%)$.

\section{Bitumen Components}

The concentrations of bitumen components in the studied sediments are given in Table 3. Asphaltenes are the prevalent part of the bitumen. Their average content for the sections amounts to 55 to 65 per cent of the whole extract. The next most widely distributed fractions are alcohol-benzene resins and hydrocarbons. In- termediate fractions are usually encountered less frequently.

There is a marked tendency for the content of hydrocarbons and light resins to increase with depth. The maximum hydrocarbon concentration, exceeding 25 per cent of the whole extract, was found in the lowermost, composite sample.

\section{Humic Acids}

It was possible to isolate humic acids in measurable quantities from six samples of Hole 416A, in two depth intervals (298-896 m and 1327-1375 m; Table 4) and from only one sample of Hole 415A (Table 5), which had the highest organic-carbon content. The largest quantity of humic acids (1080 ppm) was found in Sample $416 \mathrm{~A}-2-2,56-91 \mathrm{~cm}$, depth of 298 to 304 meters. Humic acids $(130 \mathrm{ppm})$ and traces of fulvic acid (10 $\mathrm{ppm}$ ) were isolated from Sample 416-3-3, 60-87 cm. A complete absence of components extractable with alkalis was established in the lower part of the profile of Hole 416A (alkaline solution absolutely colorless). In the other cases, alkaline extracts acquired a light-yellow color, which is indicative of humic substances in trace quantities.

\section{n-Alkanes}

The distribution of normal alkanes in the investigated samples of Holes 415A and 416A is shown in Tables 6 and 7.

A moderate predominance of odd- over even-number hydrocarbons is characteristic of all the samples. The $\mathrm{CPI}_{\text {tot }}$ coefficient (Tables 8 and 9), which characterizes the ratio between odd- and even-number hydrocarbons in a broad range from $n-\mathrm{C}_{15}$ to $n-\mathrm{C}_{31}$, is close to 2 . The $\mathrm{CPI}_{h m w}$ coefficient, which characterizes this ratio for the region of high-molecular-weight alkanes, is in most cases somewhat greater than 2 .

A noticeable predominance of odd-number alkanes is known to be characteristic of terrestrial plants. In marine plankton this predominance is smoothed off. With increase in the degree of transformation of organic matter, the odd-even ratio approaches unity, and in oils it is equal to unity. In the investigated sections, the ratio between odd- and even-number alkanes was not observed to vary systematically with depth. However, a clearly smoothed-out distribution of odd- and evennumber alkanes, which is characteristic of organic matter of a mature stage, was observed in the composite Berriasian-Valanginian sample of Hole 416A; the value of $\mathrm{CPI}_{\text {tot }}$ here is minimal (1.37).

From the chromatograms shown in Figure 3, it is seen that the base line of normal alkanes for almost all the samples has a "two-humped" shape, which seems to be associated with the specificity of the structural composition of naphthene-aromatic hydrocarbons characteristic of "immature" organic matter.

On the chromatograms taken under similar conditions for oil hydrocarbons, the alkane peaks are located on the same naphthene-aromatic "hump." It is to be noted that the chromatogram obtained for the deepest sample (Figure $3 \mathrm{~h}$ ) approaches such form. 
TABLE 1

Organic-Carbon and Bitumen Contents, Holes 415 and $415 \mathrm{~A}$

\begin{tabular}{|c|c|c|c|c|c|c|}
\hline $\begin{array}{c}\text { Sample } \\
\text { (interval in } \mathrm{cm} \text { ) }\end{array}$ & $\begin{array}{l}\text { Sub-Bottom } \\
\text { Depth } \\
\text { (m) }\end{array}$ & $\begin{array}{c}\text { Time-Stratigraphic } \\
\text { Unit }\end{array}$ & $\begin{array}{c}\text { Organic } \\
\text { Carbon } \\
(\%)\end{array}$ & $\begin{array}{c}\text { Carbonate } \\
(\%)\end{array}$ & $\begin{array}{l}\text { Total } \\
\text { Bitumen } \\
\text { in } \\
\text { Sediment } \\
\text { (ppm) }\end{array}$ & $\begin{array}{c}\text { Bitumen } \\
\text { Coefficient } \\
(\%)\end{array}$ \\
\hline $415-1-5,37-62$ & $0-7.5$ & Pleistocene & 0.12 & 71 & 83 & 7.0 \\
\hline $2-1,46-72$ & $74-83.5$ & U. Miocene-L. Pliocene & 0.13 & 76 & 63 & 5.0 \\
\hline $3-1,31-50$ & $137.5-147.0$ & M. Miocene & 0.19 & 74 & 78 & 4.0 \\
\hline $4-5,117-135$ & $207.0-216.5$ & L. Miocene-M. Miocene & 0.10 & 86 & 70 & 7.2 \\
\hline $5-2,32-59$ & $273.5-283$ & L. Miocene & 0.18 & 70 & 35 & 1.9 \\
\hline $415 \mathrm{~A}-5-1,101-126$ & $443-452.5$ & U. Paleocene & 0.19 & 50 & 141 & 6.0 \\
\hline $6-2,56-77$ & $452.5-509.5$ & L. Paleocene & 0.20 & 55 & 110 & 5.5 \\
\hline $8-1,50-80$ & $576-585.5$ & Albian-Coniacian & 1.14 & 32 & 850 & 7.7 \\
\hline $9-1,28-50$ & $642.5-652$ & M. Cenomanian & 0.66 & 50 & 470 & 7.3 \\
\hline $10-2,110-136$ & $709-718.5$ & M. Cenomanian & 0.29 & 49 & 130 & 4.5 \\
\hline $12-2,70-95$ & $880-889.5$ & M. Cenomanian & 0.68 & 39 & 270 & 4.0 \\
\hline $13-1,81-131$ & $956-965.5$ & L. Cenomanian & 0.34 & 61 & 190 & 5.7 \\
\hline $14-2,6-31$ & $1032-1041.5$ & U. Albian & 0.57 & 44 & 250 & 4.4 \\
\hline
\end{tabular}

TABLE 2

Organic-Carbon and Bitumen Contents, Hole 416A

\begin{tabular}{|c|c|c|c|c|c|c|}
\hline $\begin{array}{c}\text { Sample } \\
\text { (interval in } \mathrm{cm} \text { ) }\end{array}$ & $\begin{array}{l}\text { Sub-Bottom } \\
\text { Depth } \\
\text { (m) }\end{array}$ & $\begin{array}{c}\text { Time-Stratigraphic } \\
\text { Unit }\end{array}$ & $\begin{array}{c}\text { Organic } \\
\text { Carbon } \\
(\%)\end{array}$ & $\begin{array}{c}\text { Carbonate } \\
(\%)\end{array}$ & $\begin{array}{l}\text { Total } \\
\text { Bitumen } \\
\text { in } \\
\text { Sediment } \\
\text { (ppm) }\end{array}$ & $\begin{array}{c}\text { Bitumen } \\
\text { Coefficient } \\
(\%)\end{array}$ \\
\hline \multirow{6}{*}{$\begin{array}{c}416 \mathrm{~A}-1-1,115-140 \\
2-2,56-74 \\
79-91 \\
3-3,60-87 \\
6-3,29-75 \\
7-2,36-47 \\
48-69 \\
9-3,114-117\end{array}$} & $146-155.5$ & M. Miocene & 0.15 & 59 & 87 & 5.8 \\
\hline & $298-304.5$ & L. Miocene & 0.50 & 43 & 590 & 11.7 \\
\hline & $450-459.5$ & U. Oligocene & 0.75 & 41 & 380 & 5.1 \\
\hline & $887-896.5$ & L. Aptian & 0.58 & 24 & 280 & 4.8 \\
\hline & $991.5-1093$ & Hauterivian & 0.29 & 33 & 120 & 4.2 \\
\hline & & & & & & \\
\hline $\begin{array}{r}119-134 \\
139-143\end{array}$ & $1176.9-1185.4$ & Hauterivian & 0.36 & 44 & 150 & 4.5 \\
\hline $11-4,61-81$ & $1194.8-1204.3$ & Hauterivian & 0.39 & 35 & 200 & 5.0 \\
\hline $13-2,79-109$ & $1213.8-1222.4$ & Hauterivian & 0.38 & 36 & 300 & 5.3 \\
\hline $15-1,64-100$ & & & & & & \\
\hline $104-111$ & $1232.9-1242.5$ & Valanginian & 0.30 & 41 & 250 & 8.5 \\
\hline $143-150$ & & & & & & \\
\hline $20-2,0-50$ & $1277.5-1287$ & Valanginian & 0.40 & 40 & 220 & 5.5 \\
\hline $22-3,68-86$ & $1299.5-1309.1$ & Valanginian & 0.37 & 43 & 190 & 5.1 \\
\hline $25-1,6-60$ & $1327.7-1336.7$ & Valanginian & 0.43 & 24 & 240 & 5.6 \\
\hline $27-1,68-118$ & $1346.7-1356.2$ & Valanginian & 0.53 & 21 & 240 & 4.5 \\
\hline $29-2,10-40$ & $1365.7-1375.2$ & Valanginian & 0.41 & 22 & 220 & 5.4 \\
\hline $31-2,32-74$ & $1384.6-1394.1$ & Valanginian & 0.31 & 32 & 170 & 5.5 \\
\hline $40-3,95-125$ & $1454.5-1463.9$ & Valanginian & 0.05 & 35 & 21 & 4.0 \\
\hline $44-2,57-91$ & $1491.5-1501.2$ & Valanginian & 0.11 & 24 & 40 & 3.8 \\
\hline $47-2,108-150$ & $1520-1529.5$ & Valanginian & 0.06 & 35 & 30 & 5.3 \\
\hline $50-2,31-81$ & $1548.6-1558$ & Berriasian & 0.10 & 40 & 32 & 3.0 \\
\hline
\end{tabular}

\section{Isoprenoids}

The content of isoprenoid hydrocarbons, pristane $\left(i p-\mathrm{C}_{19}\right)$ and phytane $\left(i p-\mathrm{C}_{20}\right)$, in the deposits of Hole $416 \mathrm{~A}$ varies from 1.5 to 7 per cent of the total alkanes. In the investigated deposits of Hole $415 \mathrm{~A}$, the content of isoprenoids is 9 to 13 per cent.

The pristane-phytane ratio is often used as an indicator of the state of evolution and nature of organic matter. Along the profile of Hole $416 \mathrm{~A}$, this ratio tends to increase slightly with depth, although in the deepest sample it again becomes small (Table 8).

\section{Isotopic Composition of Carbon}

\section{Organic Matter and Bitumen}

The results of isotopic analysis of organic carbon and bitumen from the samples of Holes 415 and 415A are shown in Table 10. Isotopic composition of organic matter varies from -22.3 to -29.7 per mill. On the 
TABLE 3

Bitumen Components Eluted from a Silica-Gel Column with Various Solvents, Holes 415A and 416A

\begin{tabular}{|c|c|c|c|c|c|c|c|}
\hline \multirow[b]{2}{*}{$\begin{array}{c}\text { Sample } \\
\text { (interval in } \mathrm{cm} \text { ) }\end{array}$} & \multirow{2}{*}{$\begin{array}{l}\text { Sub-Bottom } \\
\text { Depth } \\
\text { (m) }\end{array}$} & \multirow[b]{2}{*}{$\begin{array}{c}\text { Time-Stratigraphic } \\
\text { Unit }\end{array}$} & \multicolumn{5}{|c|}{ Component Content in Sediment (ppm) } \\
\hline & & & Hexane & $\begin{array}{l}\text { Hexane- } \\
\text { Benzene }\end{array}$ & Benzene & $\begin{array}{l}\text { Benzene- } \\
\text { Methanol }\end{array}$ & Asphaltenes \\
\hline \multirow{4}{*}{$\begin{array}{c}415 \mathrm{~A}-8-1,50-80 \\
9-1,28-50 \\
12-2,70-95 \\
13-1,81-131\end{array}$} & $576-585.5$ & Albian-Coniacian & 27 & 19 & 23 & 172 & 609 \\
\hline & $642.5-652$ & M. Cenomanian & 18 & 12 & 18 & \multirow[t]{2}{*}{107} & 315 \\
\hline & $880-889.5$ & M. Cenomanian & \multicolumn{3}{|c|}{$(135)^{\mathrm{a}}$} & & 135 \\
\hline & $956-965.5$ & L. Cenomanian & 13 & 9 & 19 & 48 & 100 \\
\hline $\begin{array}{r}416 \mathrm{~A}-2-2,56-74 \\
79-91\end{array}$ & $298-304.5$ & L. Miocene & 22 & & 63 & 241 & 270 \\
\hline $3-3,60-87$ & $450-459.5$ & U. Oligocene & 20 & 22 & 8 & 83 & 246 \\
\hline $6-3,29-75$ & $887-896.5$ & L. Aptian & 29 & 12 & 6 & 51 & 182 \\
\hline $11-4,61-81$ & $1194.8-1204.3$ & Hauterivian & 17 & 11 & 2 & 37 & 134 \\
\hline $\begin{array}{l}13-2,79-109 \\
15-1,64-100\end{array}$ & $1213.8-1222.4$ & Hauterivian & 22 & 23 & 3 & 35 & 217 \\
\hline $\begin{array}{l}104-111 \\
143-150\end{array}$ & $1232.9-1242.5$ & Valanginian & 26 & 12 & 14 & 36 & 163 \\
\hline $20-2,0-50$ & $1277.5-1287$ & Valanginian & 28 & 17 & 12 & 20 & 143 \\
\hline $22-3,68-86$ & $1299.5-1309.1$ & Valanginian & 19 & 10 & 10 & 35 & 115 \\
\hline $25-1,6-60$ & $1327.7-1336.7$ & Valanginian & 35 & 20 & 14 & 45 & 126 \\
\hline $27-1,68-118$ & $1346.7-1356.2$ & Valanginian & 31 & 11 & 5 & 31 & 161 \\
\hline $\begin{array}{l}29-2,10-40 \\
44-2,57-91\end{array}$ & $1365.7-1375.2$ & Valanginian & 25 & 11 & 7 & 36 & 141 \\
\hline $\begin{array}{l}47-2,108-150 \\
50-2,31-81\end{array}$ & $1491-1558$ & $\begin{array}{l}\text { Berriasian- } \\
\text { Valanginian }\end{array}$ & 27 & 13 & 10 & 21 & 31 \\
\hline
\end{tabular}

${ }^{\text {as }}$ um of the first four components.

TABLE 4

Humic Acids, Hole 416A

\begin{tabular}{|c|c|c|c|c|c|c|}
\hline $\begin{array}{c}\text { Sample } \\
\text { (interval in } \mathrm{cm} \text { ) }\end{array}$ & $\begin{array}{l}\text { Sub-Bottom } \\
\text { Depth } \\
\text { (m) }\end{array}$ & $\begin{array}{c}\text { Time-Stratigraphic } \\
\text { Unit }\end{array}$ & $\begin{array}{l}\text { Humic Acids } \\
\text { in the Sediment } \\
(\mathrm{ppm})^{\mathrm{a}}\end{array}$ & $\begin{array}{c}\text { Ratio of } \\
\text { Humic Acids to } \\
\text { Organic Carbon } \\
(\%)\end{array}$ & $\begin{array}{c}{ }^{{ }^{13}} \mathrm{C} \text { of } \\
\text { Humic Acids } \\
(\%)\end{array}$ & $\begin{array}{c}{ }^{\Delta \delta^{13} \mathrm{C}} \\
\text { Humic Acids- } \\
\text { Organic Carbon }\end{array}$ \\
\hline $416 \mathrm{~A}-1-1,115-140$ & $146-155.5$ & M. Miocene & tr. & - & - & - \\
\hline $\begin{array}{r}2-2,56-74 \\
79-91\end{array}$ & $298-304.1$ & L. Miocene & 1080 & 20.0 & -21.44 & +0.87 \\
\hline $3-3,60-87$ & $450-459.5$ & U. Oligocene & 130 & 0.8 & - & - \\
\hline $6-3,29-75$ & $887-896.5$ & L. Aptian & 40 & 0.3 & -27.43 & +0.09 \\
\hline $\begin{array}{l}7-2,36-47 \\
48-69\end{array}$ & $991.6-1093$ & Hauterivian & tr. & - & - & - \\
\hline $\begin{array}{r}119-134 \\
139-143\end{array}$ & $1176.9-1185.4$ & Hauterivian & light yellow & - & - & - \\
\hline $11-4,61-81$ & $1194.8-1204.3$ & Hauterivian & light yellow & - & - & - \\
\hline $\begin{array}{l}13-2,79-109 \\
15-1,64-100\end{array}$ & $1213.8-1222.4$ & Hauterivian & light yellow & - & - & - \\
\hline $\begin{array}{l}104-111 \\
143-150\end{array}$ & $1232.9-1242.5$ & Valanginian & light yellow & - & - & - \\
\hline $20-2,0-50$ & $1271.5-1287$ & Valanginian & light yellow & - & - & - \\
\hline $22-3,68-86$ & $1299.5-1309.1$ & Valanginian & light yellow & - & - & - \\
\hline $25-1,6-60$ & $1327.7-1336.7$ & Valanginian & 110 & 1.87 & -24.79 & +0.48 \\
\hline $27-1,68-118$ & $1346.7-1356.2$ & Valanginian & 270 & 2.50 & -23.80 & +1.60 \\
\hline $29-2,10-40$ & $1365.7-1375.2$ & Valanginian & 77 & 1.00 & -23.18 & +3.40 \\
\hline $31-2,32-74$ & $1384.6-1394.1$ & Valanginian & uncolored & - & - & - \\
\hline $40-3,95-125$ & $1454.5-1463.9$ & Valanginian & uncolored & - & - & - \\
\hline $44-2,57-91$ & $1491.5-1501.2$ & Valanginian & uncolored & - & - & - \\
\hline $47-2,108-150$ & $1520.0-1529.5$ & Valanginian & uncolored & - & - & - \\
\hline $50-2,31-81$ & $1548.6-1558$ & Berriasian & uncolored & _- & - & - \\
\hline
\end{tabular}

${ }^{\mathrm{a} C}$ Color is that of alkaline extract (presence of humic acids uncertain). 
TABLE 5

Humic Acids, Holes 415 and 415A

\begin{tabular}{|c|c|c|c|c|c|c|}
\hline $\begin{array}{c}\text { Sample } \\
\text { (interval in } \mathrm{cm} \text { ) }\end{array}$ & $\begin{array}{l}\text { Sub-Bottom } \\
\text { Depth } \\
\text { (m) }\end{array}$ & Time-Stratigraphic Unit & $\begin{array}{l}\text { Humic Acids } \\
\text { in the Sediment } \\
(\mathrm{ppm})^{\mathrm{a}}\end{array}$ & $\begin{array}{c}\text { Ratio of } \\
\text { Humic Acids to } \\
\text { Organic Carbon } \\
(\%)\end{array}$ & $\begin{array}{c}{ }^{{ }^{13} \mathrm{C} \text { of }} \\
\text { Humic Acids } \\
(\% \circ)\end{array}$ & $\begin{array}{c}\Delta^{13} \mathrm{C} \\
\text { Humic Acids- } \\
\text { Organic Carbon }\end{array}$ \\
\hline $415-1-5,37-62$ & $0-7.5$ & Pleistocene & light yellow & - & - & - \\
\hline $2-1,46-72$ & $74-83.5$ & U. Miocene-L. Pliocene & light yellow & - & - & - \\
\hline $3-1,31-50$ & $137-147$ & M. Miocene & light yellow & - & - & - \\
\hline $4-5,117-135$ & $207-216.5$ & L. Miocene-M. Miocene & light yellow & _ & - & - \\
\hline $415 A-6-2,56-77$ & $452.5-509.5$ & L. Paleocene & uncolored & - & - & - \\
\hline $8-1,50-80$ & $576-585.5$ & Albian-Coniacian & 100 & 0.4 & -25.10 & +4.50 \\
\hline $9-1,28-50$ & $642-652$ & M. Cenomanian & yellow & - & - & - \\
\hline $10-2,110-136$ & $709-718.5$ & M. Cenomanian & light yellow & - & - & - \\
\hline $12-2,70-95$ & $880-889.5$ & M. Cenomanian & light yellow & - & - & - \\
\hline $13-2,81-131$ & $956-965.5$ & L. Cenomanian & light yellow & - & - & - \\
\hline $14-2,6-31$ & $1032-1041.5$ & U. Albian & light yellow & - & - & - \\
\hline
\end{tabular}

${ }^{\mathrm{a}}$ Color is that of alkaline extract (presence of humic acids uncertain).

TABLE 6

Alkanes, Hole 415A

(\% of total alkanes)

\begin{tabular}{lrrr}
\hline & \multicolumn{3}{c}{ Section } \\
Alkanes & \multicolumn{1}{c}{$8-1$} & \multicolumn{1}{c}{$9-1$} & $13-1$ \\
\hline$n-\mathrm{C}_{15}$ & \multicolumn{1}{c}{-} & 3.5 & 0.8 \\
$n-\mathrm{C}_{16}$ & 1.0 & 4.6 & 1.9 \\
$n-\mathrm{C}_{17}$ & 3.1 & 8.0 & 3.4 \\
$i p-\mathrm{C}_{19}$ & 1.3 & 2.8 & 2.8 \\
$n-\mathrm{C}_{18}$ & 3.1 & 5.4 & 3.5 \\
$i p-\mathrm{C}_{20}$ & 7.5 & 10.1 & 7.8 \\
$n-\mathrm{C}_{19}$ & 4.9 & 8.3 & 5.5 \\
$n-\mathrm{C}_{20}$ & 4.2 & 4.3 & 4.3 \\
$n-\mathrm{C}_{21}$ & 10.1 & 7.4 & 8.4 \\
$n-\mathrm{C}_{22}$ & 7.3 & 4.6 & 7.4 \\
$n-\mathrm{C}_{23}$ & 16.6 & 10.1 & 11.9 \\
$n-\mathrm{C}_{24}$ & 5.5 & 4.5 & 7.7 \\
$n-\mathrm{C}_{25}$ & 11.4 & 6.9 & 10.6 \\
$n-\mathrm{C}_{26}$ & 3.6 & 4.1 & 5.2 \\
$n-\mathrm{C}_{27}$ & 7.3 & 5.5 & 8.3 \\
$n-\mathrm{C}_{28}$ & 2.6 & 2.9 & 3.2 \\
$n-\mathrm{C}_{29}$ & 5.5 & 3.8 & 3.5 \\
$n-\mathrm{C}_{30}$ & 1.3 & 1.5 & 1.5 \\
$n-\mathrm{C}_{31}$ & 3.6 & 1.7 & 1.8 \\
$n-\mathrm{C}_{32}$ & - & - & 0.5 \\
\hline
\end{tabular}

whole, the section is characterized by the predominance of isotopically light organic carbon, which is more characteristic of continental than of marine organic matter. The same range of isotopic compositions is characteristic of organic carbon in the profile of Hole $416 \mathrm{~A}\left(\delta^{13} \mathrm{C}\right.$ values from -22.3 to $-29.6 \%$; Table 11$)$.

The carbon of alcohol-benzene extract (bitumen) in all samples is enriched in the ${ }^{12} \mathrm{C}$ isotope. There exists a certain zonality in the distribution of isotopic compositions of organic matter and bitumen through the section.

\section{Bitumen Fractions}

From Tables 12 and 13, which show analyses of bitumen fractions, it can be seen that there is a correla-
TABLE 7

Alkanes, Hole $416 \mathrm{~A}$ ( $\%$ of total alkanes)

\begin{tabular}{|c|c|c|c|c|c|c|c|c|c|c|c|c|}
\hline \multirow[b]{2}{*}{ Alkanes } & \multicolumn{12}{|c|}{ Section } \\
\hline & $2-2$ & $3-3$ & $6-3$ & $11-4$ & $13-2$ & $15-1$ & $20-2$ & $22-3$ & $25-1$ & $27-1$ & $29-2$ & $\begin{array}{l}47-2 \\
50-2\end{array}$ \\
\hline$-C_{15}$ & - & - & 0.4 & 0.3 & - & 0.9 & 0.7 & 0.5 & - & - & - & - \\
\hline$c_{16}$ & 0.5 & 0.5 & 2.0 & 1.4 & 0.9 & 1.9 & 2.3 & 1.2 & 1.2 & 0.7 & 1.2 & 0.6 \\
\hline & 0.7 & 1.4 & 3.6 & 4.6 & 1.9 & 3.9 & 4.9 & 2.9 & 2.4 & 1.8 & 2.2 & 1.1 \\
\hline$c_{19}$ & 0.5 & 0.5 & 1.2 & 3.3 & 2.2 & 4.1 & 4.4 & 3.1 & 2.5 & 1.7 & 2.3 & 0.5 \\
\hline $\mathrm{C}_{18}$ & 1.6 & 1.8 & 3.3 & 5.5 & 2.0 & 3.3 & 5.4 & 4.1 & 3.0 & 2.4 & 2.9 & 1.6 \\
\hline$c_{20}$ & 0.9 & 1.1 & 1.9 & 4.2 & 1.7 & 2.8 & 2.4 & 2.3 & 1.4 & 1.2 & 1.5 & 0.8 \\
\hline$n-C_{19}^{20}$ & 2.8 & 3.5 & 3.7 & 6.4 & 2.9 & 3.6 & 5.4 & 5.1 & 4.0 & 2.7 & 4.1 & 2.5 \\
\hline$n-C_{20}$ & 3.7 & 3.3 & 3.5 & 4.9 & 2.6 & 2.7 & 3.7 & 4.4 & 3.1 & 2,4 & 3.7 & 2.6 \\
\hline$n \cdot C_{21}$ & 6.2 & 5.3 & 4.5 & 5.6 & 4.9 & 4.0 & 4.9 & 5,2 & 4.6 & 5.5 & 4.8 & 4.7 \\
\hline$n-C_{22}$ & 8.3 & 5.7 & 4.8 & 5.6 & 6.0 & 4.0 & 4.9 & 5.6 & 5.2 & 7.0 & 5.1 & 6.7 \\
\hline$n-C_{23}$ & 10.5 & 8.5 & 7.1 & 7.8 & 11.0 & 7.6 & 9.5 & 9.6 & 11.0 & 10.7 & 10.0 & 9.9 \\
\hline$n-C_{24}$ & 8.8 & 7.1 & 5.5 & 4.6 & 6.6 & 5.2 & 4.8 & 6.1 & 6.7 & 9.2 & 5.8 & 9.8 \\
\hline$n-C_{25}$ & 9.7 & 10.2 & 9.6 & 9.7 & 13.3 & 10.8 & 13.3 & 11.7 & 17.1 & 13.9 & 14.3 & 10.6 \\
\hline$n-\mathrm{C}=$ & 7.4 & 7.3 & 5.8 & 4.5 & 5.4 & 5.2 & 4.3 & 5.6 & 5.4 & 7.0 & 4.9 & 9.7 \\
\hline$. \mathrm{C}=7$ & 9.2 & 11.5 & 11.3 & 12.5 & 16.2 & 12.1 & 14.0 & 12.7 & 16.1 & 14.2 & 15.6 & 11.0 \\
\hline$n-C_{28}$ & 5.8 & 6.8 & 4.9 & 4.0 & 4.4 & 4.4 & 3.0 & 4.1 & 3.3 & 4.5 & 4.0 & 7.3 \\
\hline & 10.2 & 11.3 & 12.6 & 7.1 & 8.5 & 9.2 & 6.3 & 7,5 & 7.0 & 6.7 & 8.7 & 8.1 \\
\hline$n-C_{30}$ & 3.8 & 5.7 & 3.2 & 2.8 & 2.7 & 4.7 & 11.8 & 2.8 & 2.1 & 2.4 & 2.6 & 4.8 \\
\hline$n-\mathrm{C}_{31}$ & 8.3 & 8.4 & 9.0 & 5.2 & 5.1 & 6.8 & 4.1 & 5.6 & 3.9 & 4.1 & 5.1 & 5.9 \\
\hline$n-C_{32}$ & 1.4 & - & 1.9 & - & 1.7 & 2.8 & - & - & - & 1.6 & 1.3 & 1.9 \\
\hline
\end{tabular}

tion between bitumen-component polarity and isotopic composition of its carbon. Asphaltenes are distinguished by a relatively low light-isotope content in all the samples. The hydrocarbons, on the contrary, are most of all enriched in the light isotope.

It proved to be characteristic of the studied samples that when organic carbon is enriched in the light isotope, bitumen fractions have a similar isotopic composition. For each sample, coefficients of dispersion in isotopic composition were calculated for bitumen fractions. As seen from Table 12, the intervals which contain the isotopically light carbon are more often characterized by low dispersion-coefficient values, and vice versa.

It is also noteworthy that the dispersion coefficients, which characterize the variability in carbon-isotope composition of the fractions through the sections, are higher for asphaltenes and the polar fractions than for hydrocarbons. 
TABLE 8

Aliphatic-Hydrocarbon Ratios, Hole 416A

\begin{tabular}{|c|c|c|c|c|c|c|c|}
\hline $\begin{array}{c}\text { Sample } \\
\text { (interval in } \mathrm{cm} \text { ) }\end{array}$ & $\begin{array}{l}\text { Sub-Bottom } \\
\text { Depth } \\
\text { (m) }\end{array}$ & $\begin{array}{c}\text { Time-Stratigraphic } \\
\text { Unit }\end{array}$ & $\mathrm{CPI}_{\text {tot }}$ & $\mathrm{CPI}_{\mathrm{hmw}}$ & $\frac{i p-C_{19}}{i p-C_{20}}$ & $\frac{n-C_{25}+n-C_{27}}{n-C_{29}+n-C_{31}}$ & $\frac{n-C_{27}}{n-C_{17}}$ \\
\hline \multicolumn{5}{|l|}{$416 \mathrm{~A}-2-2,56-74$} & & & \\
\hline $3-3,60-87$ & $450-459.5$ & U. Oligocene & 1.6 & 1.8 & 0.5 & 1.1 & 8.3 \\
\hline $6-3,29-75$ & $887-896.5$ & L. Aptian & 1.9 & 2.4 & 0.6 & 1.0 & 3.1 \\
\hline $11-4,61-81$ & $1194.8-1204.3$ & Hauterivian & 1.8 & 2.6 & 0.8 & 1.8 & 2.8 \\
\hline $\begin{array}{l}13-2,79-109 \\
15-1,64-100\end{array}$ & $1213.8-1222.4$ & Hauterivian & 2.1 & 2.6 & 1.3 & 2.2 & 8.6 \\
\hline $\begin{array}{l}104-111 \\
143-150\end{array}$ & $1232.9-1242.5$ & Valanginian & 1.8 & 2.1 & 1.5 & 1.4 & 3.2 \\
\hline $20-2,0-50$ & $1277.5-1287$ & Valanginian & 2.1 & 2.9 & 1.8 & 2.6 & 2.8 \\
\hline $22-3,68-86$ & $1299.5-1309.1$ & Valanginian & 1.8 & 2.5 & 1.3 & 1.9 & 4.4 \\
\hline $25-1,6-60$ & $1327.7-1336.7$ & Valanginian & 1.7 & 2.3 & 1.4 & 2.6 & 7.8 \\
\hline $27-1,68-118$ & $1346.7-1356.2$ & Valanginian & 2.2 & 3.3 & 1.7 & 3.0 & 6.7 \\
\hline $\begin{array}{l}29-2,10-40 \\
44-2,57-91\end{array}$ & $1365.7-1375.2$ & Valanginian & 2.2 & 3.0 & 1.6 & 2.2 & 7.0 \\
\hline $\begin{array}{l}47-2,108-150 \\
50-2,31-81\end{array}$ & $1491.5-1558$ & Berriasian-Valanginian & 1.3 & 1.5 & 0.6 & 1.3 & 11.8 \\
\hline
\end{tabular}

TABLE 9

Aliphatic-Hydrocarbon Ratios, Hole 415A

\begin{tabular}{cccccccc}
\hline $\begin{array}{c}\text { Sample } \\
\text { (interval in cm) }\end{array}$ & $\begin{array}{c}\text { Sub-Bottom } \\
\text { Depth } \\
(\mathrm{m})\end{array}$ & $\begin{array}{c}\text { Time-Stratigraphic } \\
\text { Unit }\end{array}$ & $\mathrm{CPI}_{\text {tot }}$ & $\mathrm{CPI}_{h m w}$ & $\frac{i p-\mathrm{C}_{19}}{i p-\mathrm{C}_{20}}$ & $\frac{n-\mathrm{C}_{25}+n-\mathrm{C}_{27}}{n-\mathrm{C}_{29}+n-\mathrm{C}_{31}}$ & $\frac{n-\mathrm{C}_{27}}{n-\mathrm{C}_{17}}$ \\
\hline 415A-8-1, 50-80 & $576-585.5$ & Albian-Coniacian & 2.9 & 2.2 & 0.2 & 3.2 & 2.3 \\
$9-1,28-50$ & $642.5-652$ & M. Cenomanian & 1.7 & 1.6 & 0.3 & 2.2 & 0.7 \\
$13-1,70-95$ & $956-965.5$ & L. Cenomanian & 1.8 & 1.5 & 0.4 & 3.6 & 2.4 \\
\hline
\end{tabular}

\section{Plant Fragments and Amber}

Residues of higher plants, coal veinlets, and amber grains were found in several samples (Plate 1).

Isotopic-composition analyses for these samples are summarized in Table 14. The organic carbon of plant fragments proved to be much less enriched in the light isotope than the scattered carbon from the same intervals.

The carbon of amber turned out to be relatively heavy isotopically $\left(\delta^{13} \mathrm{C}=-22.6 \% \infty\right)$. This is evidently determined by its composition. Abundance of $\mathrm{C}=\mathrm{O}$ bonds, in accordance with the concept of thermodynamic isotopic effects in biological systems, could explain the relative scarcity of the light isotope in the amber.

\section{Spectroscopy in the Visible-Light Region}

Spectral data for Holes 415 and $415 \mathrm{~A}$ are given in Table 15. Analysis of these data indicates the presence of tetrapyrrole pigments in all the sediments of the investigated sections. The main absorption bands characteristic of the free bases of chlorins $(400 \mathrm{~nm}$ [Soret band], $660 \mathrm{~nm}$ ) are detectable in the spectra of total bitumen and are more clearly manifested in the spectra of the asphaltene and benzene-methanol fractions in young sediments down to a depth of 450 meters. Pigments of the porphyrin type were not spectrally detected in these samples. Starting at a depth of 450 meters, the chlorin peak at $660 \mathrm{~nm}$ disappears in the spectra of total bitumen, and the Soret peak shifts towards shorter wave lengths by 2 to $5 \mathrm{~nm}$. In the asphaltene and benzenemethanol fractions, however, the chlorine peaks (400$405,600,620 \mathrm{~nm}$ ) are still seen in all the samples. Metal porphyrins were first spectrally detected in Sample 415A-6-2, 56-77 cm (depth 452-509 m, lower Paleocene). Between 575 to 585 meters and the bottom of the section in Hole 415, the spectra of total bitumen have, along with the $395-\mathrm{nm}$ peak, a clearly defined second porphyrin peak at $553 \mathrm{~nm}$ which is typical of nickel porphyrins. The hexane-benzene fractions of these samples have in their visible-light spectra clearly defined absorption bands at 395,515 , and $553 \mathrm{~nm}$, which makes it possible to identify nickel porphyins of the DPEP and the etio types. In Samples 415A-13-1, 81-131 cm and 415A-14-2, 6-31 cm, taken from the deepest sediments of Hole $415 \mathrm{~A}$, a peak at $585 \mathrm{~nm}$, usually attributed to nickel porphyrins of the rhodo type, appears in the spectra.

The distribution of tetrapyrrole pigments in the profile of Hole 416A is similar (Table 16).

Free bases of chlorins are characteristic of young sediments. The concentration of chlorins in the samples decreases with depth, but they are detected to at least a depth of about 1330 meters. In the bitumen spectrum of Sample 416A-25-1, 6-60 cm (depth $1330 \mathrm{~m}$, Valangin- 


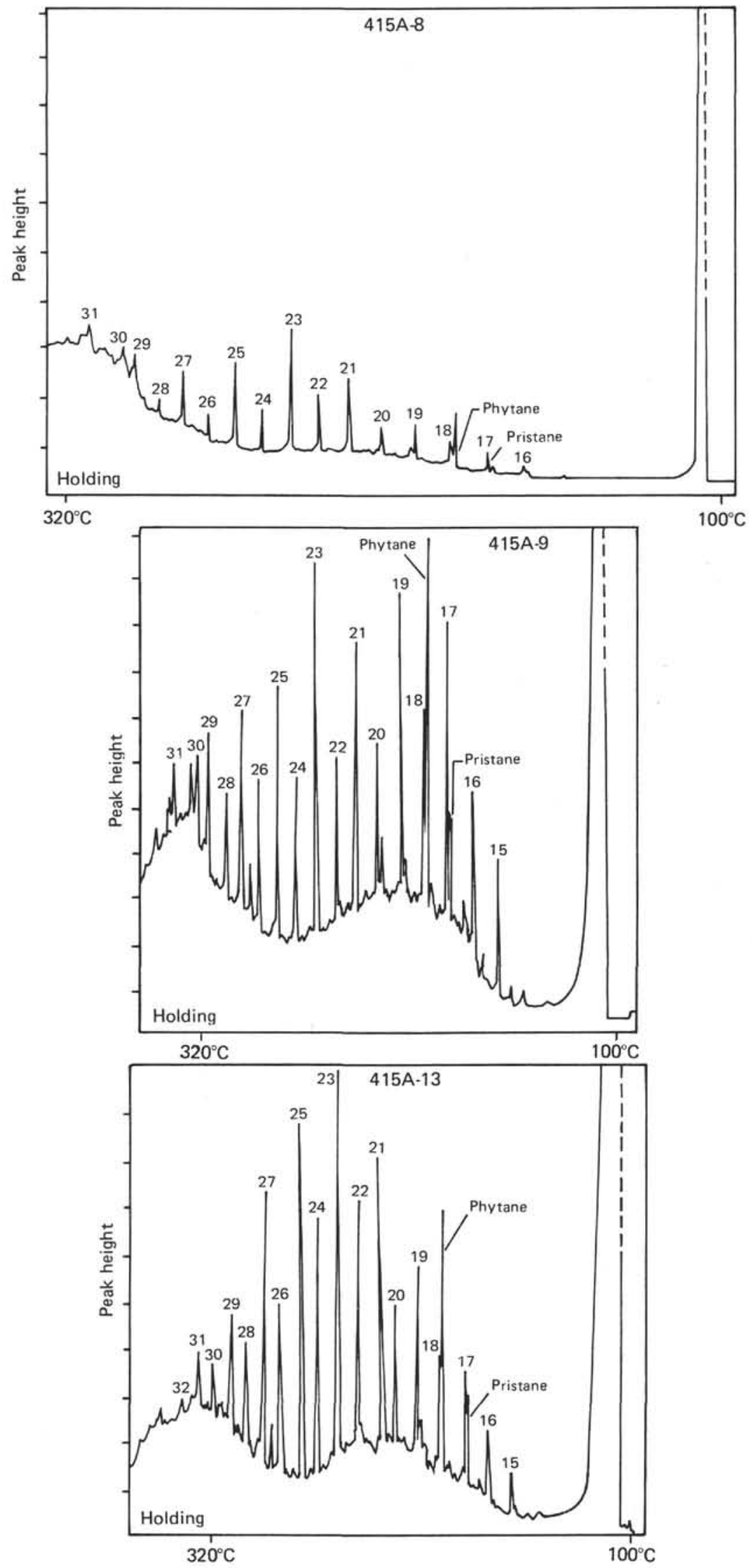

Figure 3. Gas chromatograms of the hydrocarbon fractions from samples of the indicated cores, Site 415 and 416. 

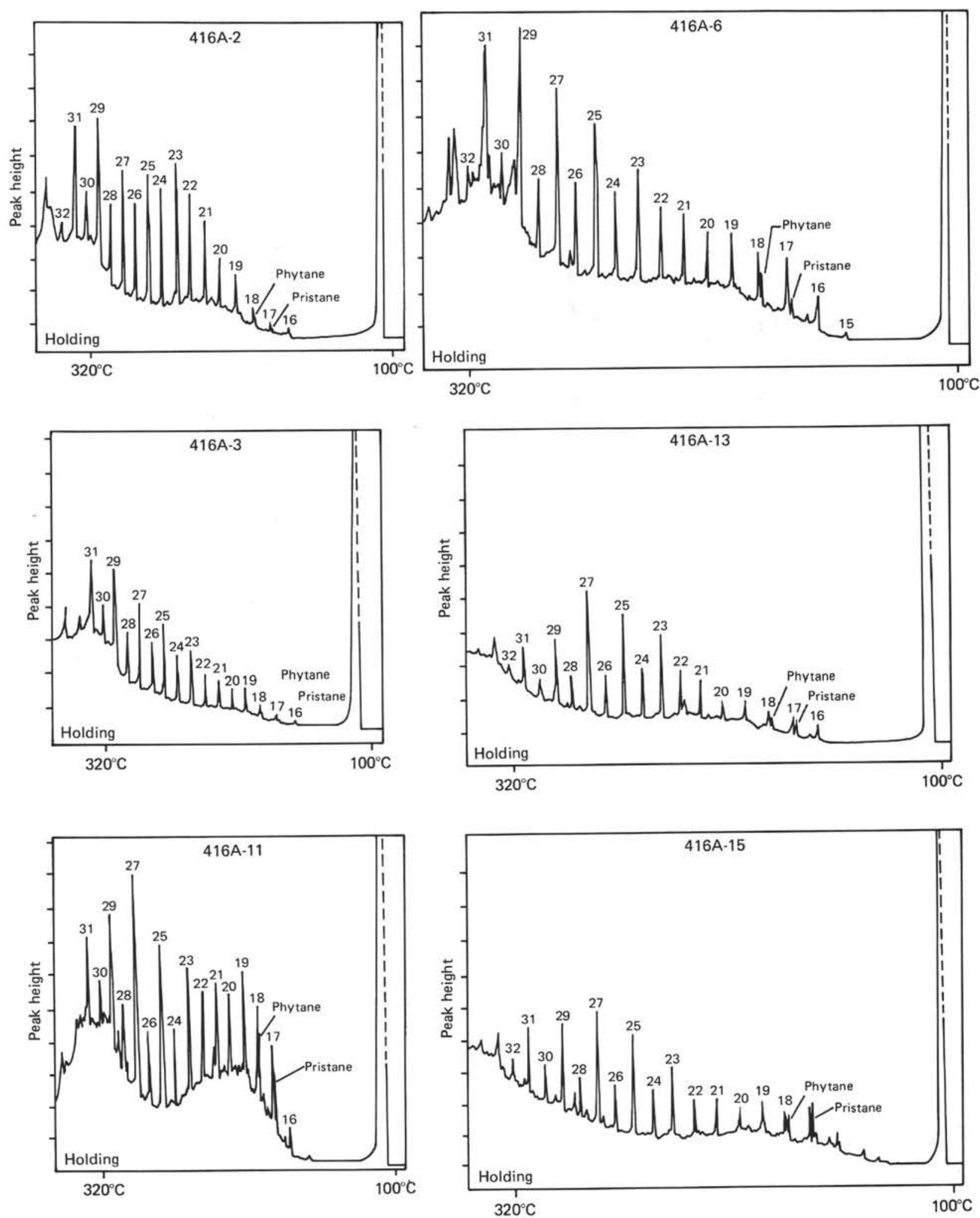

Figure 3. Continued. 

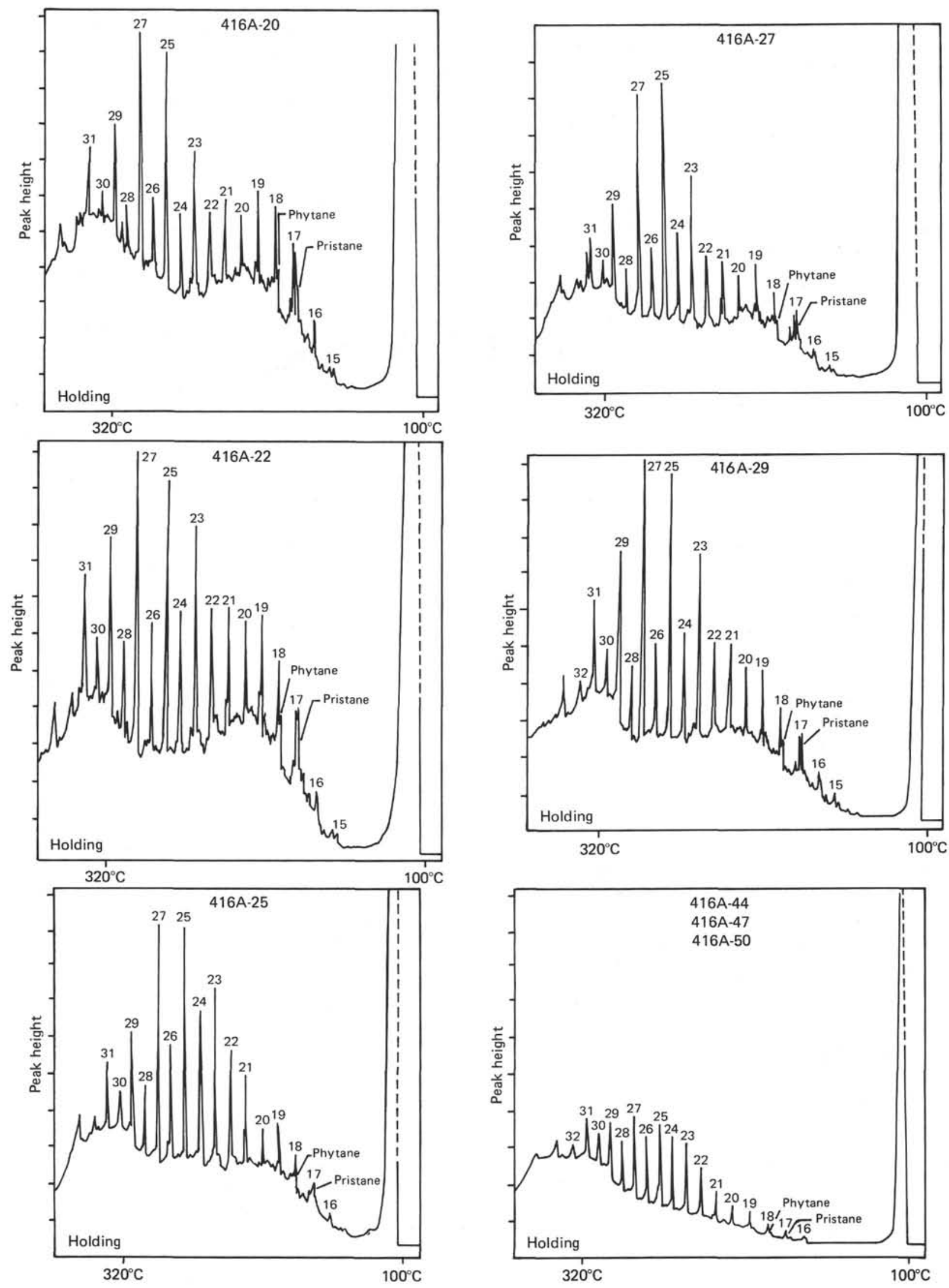

Figure 3. Continued. 
TABLE 10

Carbon-Isotope Composition of Organic Matter and Bitumen (benzene-methanol [9:1] extract), Holes 415 and 415A

\begin{tabular}{|c|c|c|c|c|c|}
\hline \multirow[b]{2}{*}{$\begin{array}{c}\text { Sample } \\
\text { (interval in } \mathrm{cm} \text { ) }\end{array}$} & \multirow[b]{2}{*}{$\begin{array}{l}\text { Sub-Bottom } \\
\text { Depth } \\
\text { (m) }\end{array}$} & \multirow[b]{2}{*}{ Time-Stratigraphic Unit } & \multicolumn{2}{|c|}{$\delta^{13}(\%(\%)$} & \multirow{2}{*}{$\begin{array}{c}\frac{\Delta \delta^{13} \mathrm{C}}{} \\
\text { Bitumen- } \\
\text { Organic } \\
\text { Matter }\end{array}$} \\
\hline & & & $\begin{array}{l}\text { Total } \\
\text { Organic } \\
\text { Matter }\end{array}$ & Bitumen & \\
\hline $415-1-5,37-62$ & $0-7.5$ & Pleistocene & -23.85 & -27.11 & -3.26 \\
\hline $2-1,46-72$ & $74-83.5$ & U. Miocene-L. Pliocene & -23.18 & -27.58 & -4.40 \\
\hline $3-1,31-50$ & $137.5-147$ & M. Miocene & -22.34 & -25.27 & -2.93 \\
\hline $4-5,117-135$ & $207.0-216.5$ & L. Miocene-M. Miocene & -23.52 & -26.90 & -3.38 \\
\hline $5-2,32-59$ & $273.5-283$ & L. Miocene & -23.30 & -26.22 & -2.92 \\
\hline $415 \mathrm{~A}-5-1,101-126$ & $443-452.5$ & U. Paleocene & -26.65 & -28.12 & -1.47 \\
\hline $6-2,56-77$ & $452.5-509.5$ & L. Palcocene & -27.76 & -29.06 & -1.30 \\
\hline $8-1,50-80$ & $576-585.5$ & Albian-Coniacian & -29.60 & -31.41 & $-1,81$ \\
\hline $9-1,28-50$ & $642.5-652$ & M. Cenomanian & -29.70 & -31.61 & -1.91 \\
\hline $10-2,110-136$ & $709-718.5$ & M. Cenomanian & -27.22 & -29.10 & -1.88 \\
\hline $12-2,70-95$ & $880-889.5$ & M. Cenomanian & -28.64 & -30.32 & -1.68 \\
\hline $13-1,81-131$ & $956-965.5$ & L. Cenomanian & -29.70 & -30.31 & -0.61 \\
\hline $14-2,6-31$ & $1032-1041.5$ & U. Albian & -27.79 & -29.89 & -2.10 \\
\hline
\end{tabular}

TABLE 11

Carbon-Isotope Composition of Organic Matter and Bitumen (benzene-methanol [9:1] extract), Hole 416A

\begin{tabular}{|c|c|c|c|c|c|}
\hline \multirow[b]{2}{*}{$\begin{array}{c}\text { Sample } \\
\text { (interval in cm) }\end{array}$} & \multirow[b]{2}{*}{$\begin{array}{l}\text { Sub-Bottom } \\
\text { Depth } \\
\text { (m) }\end{array}$} & \multirow[b]{2}{*}{$\begin{array}{c}\text { Time-Stratieraphic } \\
\text { Unit }\end{array}$} & \multicolumn{2}{|c|}{$\delta^{13} \mathrm{C}(\%)$} & \multirow{2}{*}{ 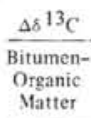 } \\
\hline & & & $\begin{array}{c}\text { Total } \\
\text { Organic } \\
\text { Matter }\end{array}$ & Bitumen & \\
\hline $416 \mathrm{~A}-1-1,115-140$ & $146-155.5$ & M. Miocene & -26.60 & -27.35 & +0.75 \\
\hline $\begin{array}{r}2-2,56-74 \\
79-91\end{array}$ & $298-304.5$ & L. Miocene & -22.31 & -25.70 & -3.39 \\
\hline $\begin{array}{l}3-3,60-87 \\
6-3,29-75\end{array}$ & $\begin{array}{l}450-459.5 \\
887-896.5\end{array}$ & U. Oligocene & -22.76 & -25.53 & -2.77 \\
\hline $7-2,36-47$ & $887-896.5$ & L. Aptian & -27.52 & -29.36 & -1.84 \\
\hline $\begin{aligned} 48-69 \\
9-3,114-117\end{aligned}$ & $991.5-1093$ & Hauterivian & -28.45 & -29.69 & -1.24 \\
\hline $\begin{array}{r}119-134 \\
139-143\end{array}$ & $1176.9-1185.4$ & Hauterivian & -26.60 & -29.85 & -3.25 \\
\hline$|1-4,61-8|$ & $1194.8-1204.3$ & Hauterivian & -28.25 & -29.56 & -1.31 \\
\hline $\begin{array}{l}13-2,79-109 \\
15-1,64-100\end{array}$ & $1213.8-1222.4$ & Hauterivian & -27.91 & -28.40 & -0.49 \\
\hline $\begin{array}{l}104-111 \\
143-150\end{array}$ & $1232.9-1242.5$ & Valanginian & -29.57 & -30.49 & -0.92 \\
\hline $20-2,0-50$ & $1277.5-1287$ & Valanginian & -28.16 & -29.54 & -1.38 \\
\hline $22-3,68-86$ & $1299.5-1309.1$ & Valanginian & -28.31 & -29.49 & -1.18 \\
\hline $25-1,6-60$ & $1327.7-1336.7$ & Valanginian & -25.47 & -27.52 & -2.25 \\
\hline $27-1,68-118$ & $1346.7-1356.2$ & Valanginian & -25.40 & -26.28 & -0.88 \\
\hline $29-2,10-40$ & $1365.7-1375.2$ & Valanginian & -26.58 & -27.87 & -1.29 \\
\hline $31-2,32-74$ & $1384.6-1394.1$ & Valanginian & -25.77 & -27.57 & -1.80 \\
\hline $40-3,95-125$ & $1454.5-1463.9$ & Valanginian & -26.39 & -27.98 & -1.59 \\
\hline $44-2,57-91$ & $1491.5-1501.2$ & Valanginian & -26.12 & -27.77 & -1.65 \\
\hline $47-2,108-150$ & $1520-1529.5$ & Valanginian & -26.51 & -28.55 & -2.04 \\
\hline $50-2,31-81$ & $1548.6-1558$ & Berriasian & -26.15 & -28.87 & -2.75 \\
\hline
\end{tabular}

ian), fairly clear chlorin peaks $(410,635,660 \mathrm{~nm})$ are seen.

In Sample 416A-6-3, 29-75 cm (depth $887 \mathrm{~m}$, lower Aptian) and below, metal porphyrins appear in the sediments. These are revealed by a shift in the Soret peak to $395 \mathrm{~nm}$. The maximum contents of nickel porphyrins were at depths of 1210 to 1370 meters. The hexane-benzene fractions of bitumens in this interval give clear spectra of nickel porphyrins of the DPEP and etio types $(395,515,553 \mathrm{~nm})$.

Besides spectra of tetrapyrrole structures, absorption bands characteristic of polycyclic aromatics $(385,409$, $428,435 \mathrm{~nm}$ ) appear in the visible-light spectra of the studied samples. Band intensity decreases in the direction of shorter wave lengths. The maximal intensity is that of the peak at $434 \mathrm{~nm}$. In Hole $415 \mathrm{~A}$, the spectrum corresponding to polycyclic aromatics appears in Sample $415 \mathrm{~A}-8-1,50-80 \mathrm{~cm}$ (depth $576-585.5 \mathrm{~m}$, Albian-Coniacian) and is seen in all lower samples. In Hole $416 \mathrm{~A}$, these absorption bands are first seen in Sample 416A-11-4, 61-81 cm (depth 1194.8-1204.3 m, Hauterivian) and are especially distinct in Sample
$416 \mathrm{~A}-15-1,64-150 \mathrm{~cm}$. The polycyclic aromatics can be regarded as represented by the perylene-type structures, if one assumes that the fifth, least intensive peak characteristic of perylene structures $(362 \mathrm{~nm})$ was not seen in most spectra because of the low concentration of matter in the sample. It is to be noted that in the spectrum of Sample 416A-15-1, 64-150 cm the 362-nm peak is actually present.

\section{ESR-Spectroscopy}

Figure 4 shows typical ESR spectra for bitumens in oceanic sedimentary rocks and their variation through the sections. In the upper sediments, the ESR spectrum is typical of a divalent-copper complex with four equivalent nitrogen atoms, most probably in the form of complexes with chlorin structures (Figure 4a). Judging by the number of lines of additional superfine structure from ${ }^{14} \mathrm{~N}$ on the additional absorption peak, divalent copper is bonded with two nitrogen atoms. The position of the additional absorption peak corresponds to a $g$ factor of 1.978. The ESR-spectrum parameters for the bitumens of sedimentary rocks in the upper parts of the section correspond to those for copper in complexes with porphyrins.

In the ESR spectra of bitumens of lower-lying rocks, absorption lines of free radicals with a $g$-factor of 2.0028 appear, along with those of divalent copper (Figure 4b).

Below a depth of 900 meters, the ESR spectra of the bitumens become highly distorted, and additional lines appear which do not belong to the divalent-copper spectrum (Figure 4c). Also, the signal intensity of the ESR of free radicals increases several times. In spectrum shown, a narrow signal which does not belong to the copper ESR spectrum is seen next to the radical signal. This signal was conjecturally assigned by us to the most intensive line of the tetravalent-vanadium ESR spectrum.

Figure $4 \mathrm{~d}$ shows the ESR spectrum for bitumen in the lowermost sedimentary rocks. This spectrum is simplified, owing, as it seems, to the decreasing quantity of paramagnetic metals in the bitumen. The most intensive signal in the ESR spectrum is that of the free radical. However, the number of free radicals per unit of bitumen decreases, although in general the number of free radicals tends to increase with depth.

\section{IR-Spectroscopy}

In the infrared-region absorption spectra of bitumens, regular variations were noted for bands in the regions of 1740,1720 to 1700 , and 1600 to $720 \mathrm{~cm}^{-1}$.

In samples from the upper parts of Hole 415A, an intensive band which corresponds to the $\mathrm{C}=\mathrm{O}$ groups of aliphatic ethers was observed at $1740 \mathrm{~cm}^{-1}$ (Figure 5). Lower in the section, the absorption band of $\mathrm{C}=\mathrm{O}$ groups was observed to shift to the region of 1700 to $1720 \mathrm{~cm}^{-1}$.

The spectral characteristics of samples from the upper part of Hole $416 \mathrm{~A}$ are similar (Figure 6). In samples from Sections $416 \mathrm{~A}-1-1$ and $416 \mathrm{~A}-2-2$, the $1740-\mathrm{cm}^{-1}$ band is clearly revealed. In lower samples, this band is 
TABLE 12

Carbon-Isotope Composition of Bitumen Fractions, Hole 416A

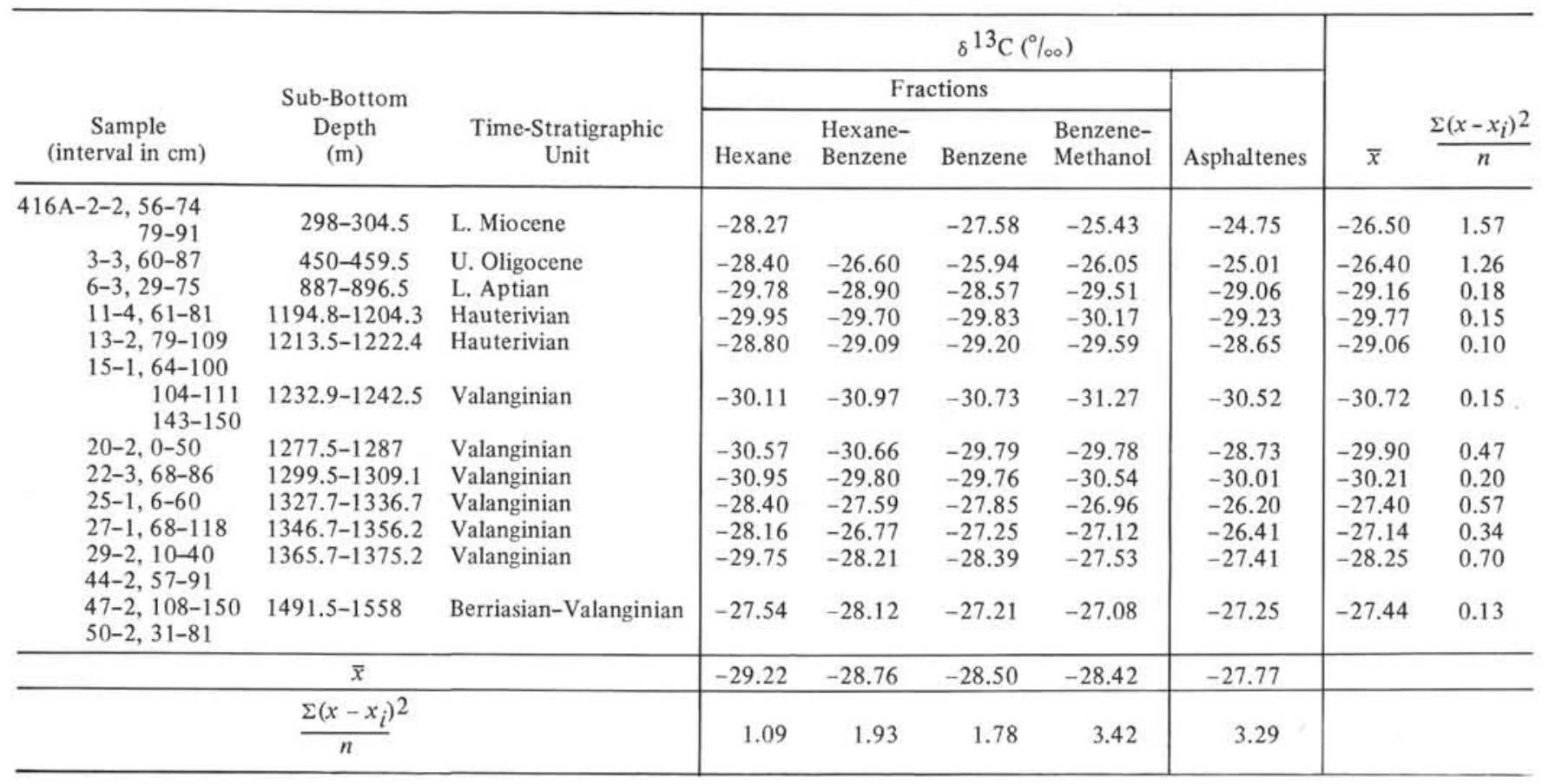

TABLE 13

Carbon-Isotope Composition of Bitumen Fractions, Hole 415A

\begin{tabular}{|c|c|c|c|c|c|c|c|c|c|}
\hline \multirow{2}{*}{$\begin{array}{c}\text { Sample } \\
\text { (interval in } \mathrm{cm} \text { ) }\end{array}$} & \multirow{2}{*}{$\begin{array}{l}\text { Sub-Bottom } \\
\text { Depth } \\
\text { (m) }\end{array}$} & \multirow{3}{*}{ Time-Stratigraphic Unit } & \multicolumn{5}{|c|}{$\delta^{13} \mathrm{C}(\%)$} & \multirow{3}{*}{$\bar{x}$} & \multirow{2}{*}{$\frac{\Sigma\left(x-x_{i}\right)^{2}}{n}$} \\
\hline & & & & Hexane- & & Benzene- & \multirow{2}{*}{ Asphaltenes } & & \\
\hline & & & & & & & & & \\
\hline \multirow{3}{*}{$\begin{array}{c}415 \mathrm{~A}-8-1,50-80 \\
9-1,28-50 \\
12-2,70-95 \\
13-1,81-131\end{array}$} & $576-585.5$ & Albian-Coniacian & -31.37 & -30.97 & -31.81 & -31.67 & -31.22 & -31.41 & 0.09 \\
\hline & $642.5-652$ & M. Cenomanian & -31.22 & -31.09 & -31.47 & -30.87 & -31.13 & -31.16 & 0.05 \\
\hline & $880-889.5$ & M. Cenomanian & \multicolumn{4}{|c|}{$(-30.40)^{\mathrm{a}}$} & -29.97 & -30.18 & 0.05 \\
\hline
\end{tabular}

$\mathrm{a}_{\delta}{ }^{13} \mathrm{C}$ of the sum of the four fractions.

TABLE 14

Petrographic Description and Carbon-Isotope Composition of Plant Fragments and Amber

\begin{tabular}{|c|c|c|c|c|}
\hline \multirow{2}{*}{$\begin{array}{c}\text { Sample } \\
\text { (interval in } \mathrm{cm} \text { ) }\end{array}$} & \multirow[b]{2}{*}{ Description } & \multicolumn{2}{|c|}{$\underline{\text { Reflectance }(\%)}$} & \multirow{2}{*}{$\frac{\delta^{13} \mathrm{C}}{(\%)}$} \\
\hline & & $R_{\text {max }}^{a}$ & $R_{\text {min }}^{a}$ & \\
\hline $416 \mathrm{~A}-16-2,91-92$ & $\begin{array}{l}\text { Fragments of plant tissue; reddish-brown, rather homoge- } \\
\text { neous collinite with slight trace of cellular structure; main } \\
\text { body of organic material of vitrain type; stage of coalifica- } \\
\text { tion sub-bituminous C. (Plate 1, Figure } 3 \text { ). }\end{array}$ & 6.4 & 5.9 & -24.93 \\
\hline $416 \mathrm{~A}-23-2,98-101$ & $\begin{array}{l}\text { Collinite, red-brown; fragments of plant tissue coated with } \\
\text { cuticula; organic matter of fragments collinite type (struc- } \\
\text { tureless) and partly telinite type; transition from lignite to } \\
\text { sub-bituminous C (Plate 1, Figure } 4 \text { ). }\end{array}$ & 6.2 & 5.8 & -24.92 \\
\hline $416 \mathrm{~A}-24-2,58-59$ & $\begin{array}{l}\text { Large fragment of wood tissue; structural vitrain (telinite); } \\
\text { unclear cellular structure; sub-bituminous C. (Plate 1, Fig- } \\
\text { ure 5). }\end{array}$ & 6.5 & 6.3 & -24.19 \\
\hline $416 \mathrm{~A}-24-2,62-63$ & $\begin{array}{l}\text { Homogeneous substance, red-brown; product of gelifica- } \\
\text { tion of plant tissues; no trace of cellular structure; collinite; } \\
\text { pyrite grains; lignite. (Plate 1, Figure } 6 \text { ). }\end{array}$ & 6.2 & 5.8 & -23.99 \\
\hline $416 \mathrm{~A}-16-2,91-92$ & Amber. (Plate 1, Figures 1, 2). & - & - & -22.60 \\
\hline
\end{tabular}


TABLE 15

Visible-Light Absorption Spectra of Bitumen and Bitumen Fractions, Holes 415 and 415A

\begin{tabular}{|c|c|c|c|c|c|c|c|c|}
\hline \multirow[b]{2}{*}{$\begin{array}{c}\text { Sample } \\
\text { (interval in } \mathrm{cm} \text { ) }\end{array}$} & \multirow{2}{*}{$\begin{array}{l}\text { Sub-Bottom } \\
\text { Depth } \\
\text { (m) }\end{array}$} & \multirow[b]{2}{*}{ Time-Stratigraphic Unit } & \multirow{2}{*}{$\begin{array}{l}\text { Bitumen, or } \\
\text { Bitumen } \\
\text { Fraction }\end{array}$} & \multicolumn{4}{|c|}{$\begin{array}{c}\text { Visible-light } \\
\text { Absorption Spectra } \\
\end{array}$} & \multirow[b]{2}{*}{ Compounds } \\
\hline & & & & & & & & \\
\hline $415-1-5,37-62$ & $0-7.5$ & Pleistocene & Bitumen & 400 & 660 & & & Chlorins \\
\hline $2-1,46-72$ & $74-83.5$ & U. Miocene-L. Pliocene & Bitumen & 400 & 660 & & & Chlorins \\
\hline $3-1,31-50$ & $137.5-147.0$ & M. Miocene & Bitumen & 400 & 600 & 660 & & Chlorins \\
\hline $4-5,117-135$ & $207.0-216.5$ & L. Miocene-M. Miocene & Bitumen & 400 & & & & Chlorins \\
\hline $5-2,32-59$ & $273.5-283.0$ & L. Miocene & Bitumen & 400 & 600 & 655 & & Chlorins \\
\hline $415 A-5-1,101-126$ & $443.0-452.5$ & U. Paleocene & Bitumen & 400 & & & & Chlorins \\
\hline $6-2,56-77$ & $452.5-509.5$ & L. Paleocene & Bitumen & 397 & & & & Metalloporphyrins \\
\hline \multirow{4}{*}{$8-1,50-80$} & $576.0-585.5$ & Albian-Coniacian & Bitumen & 395 & 550 & & & Nickel porphyrins \\
\hline & & & Hexane & 385 & 408 & 428 & 435 & $\begin{array}{l}\text { Polycyclic aromatic } \\
\text { (perylene type) }\end{array}$ \\
\hline & & & $\begin{array}{l}\text { Benzene- } \\
\text { Methanol }\end{array}$ & 398 & 520 & 555 & 590 & $\begin{array}{l}\text { Nickel porphyrins } \\
\text { (DPEP, etio, } \\
\text { rhodo types) }\end{array}$ \\
\hline & & & Asphaltenes & 405 & 600 & & & Chlorins \\
\hline \multirow[t]{4}{*}{$9-1,28-50$} & $642.5-652.0$ & M. Cenomanian & Bitumen & 397 & & & & Metalloporphyrins \\
\hline & & & Hexane & 385 & 408 & 428 & 435 & $\begin{array}{l}\text { Polycyclic aromatics } \\
\text { (perylene type) }\end{array}$ \\
\hline & & & $\begin{array}{l}\text { Hexane- } \\
\text { Benzene }\end{array}$ & 395 & & 550 & & Nickel porphyrins \\
\hline & & & Asphaltenes & 400 & & 600 & & Chlorins \\
\hline $10-2,110-136$ & $709.0-718.5$ & M. Cenomanian & Bitumen & 400 & & 550 & & Nickel porphyrins \\
\hline \multirow{3}{*}{$12-2,70-95$} & $880.0-889.5$ & M. Cenomanian & Bitumen & 395 & & 550 & & Nickel porphyrins \\
\hline & & & Pentane $^{a}$ & 398 & 515 & 553 & 585 & $\begin{array}{l}\text { Nickel porphyrins } \\
\text { (DPEP, etio, } \\
\text { rhodo types) }\end{array}$ \\
\hline & & & Pentane & $(400)$ & & & 620 & Chlorins \\
\hline \multirow[t]{5}{*}{$13-1,81-131$} & $956.0-965.5$ & L. Cenomanian & Bitumen & 395 & 515 & 553 & & $\begin{array}{l}\text { Nickel porphyrins } \\
\text { (DPEP, etio types) }\end{array}$ \\
\hline & & & Hexane & 380 & 408 & 428 & 435 & $\begin{array}{l}\text { Polycyclic aromatics } \\
\text { (perylene type) }\end{array}$ \\
\hline & & & $\begin{array}{l}\text { Hexane- } \\
\text { Benzene }\end{array}$ & 398 & 515 & 553 & & $\begin{array}{l}\text { Nickel porphyrins } \\
\text { (DPEP, etio types) }\end{array}$ \\
\hline & & & Benzene & 400 & 515 & 553 & 585 & $\begin{array}{l}\text { Nickel porphyrins } \\
\text { (DPEP, etio, } \\
\text { rhodo types) }\end{array}$ \\
\hline & & & Asphaltenes & 400 & 630 & & & Chlorins \\
\hline $14-2,6-31$ & $1032.0-1041.5$ & U. Albian & Bitumen & 395 & 555 & & & Nickel porphyrins \\
\hline
\end{tabular}

${ }^{a}$ Sum of hexane, hexane-benzene, benzene, benzene-methanol.

shifted toward lower frequencies. In the upper samples, the relative intensity of the $1740-\mathrm{cm}^{-1}$ band is much higher than that of the $1600-\mathrm{cm}^{-1}$ band, that represents the aromatic structures. At and below Section 416A-7-2 (991.5-1093 m, Hauterivian), the intensities of absorption bands of $\mathrm{C}=\mathrm{O}$ groups $\left(1740,1700-1720 \mathrm{~cm}^{-1}\right)$ and aromatic structures $\left(1600 \mathrm{~cm}^{-1}\right)$ are approximately equalized. In the lowermost samples, the $1740-\mathrm{cm}^{-1}$ band appears again, with an intensity approximately double that of the $1600-\mathrm{cm}^{-1}$ band. In these same samples, the absorption band of long aliphatic chains $\left(720 \mathrm{~cm}^{-1}\right)$ is clearly defined.

\section{DISCUSSION}

Dispersed organic-carbon content in the investigated samples varied from 0.05 to 1.14 per cent. Two zones are distinguished in the sediments of Hole 415A, above and below 500 meters. Organic-carbon content in the upper zone is low (on the average $0.15 \%$ ); the lower deposits contain more (Figure 7). Organic-carbon con- tent in samples of Holes 416A varies from 0.05 to 0.75 per cent and does not show any systematic variation with depth or stratigraphic subdivision (Figure 8). The minimum organic-carbon content was noted among the lowermost samples. On the average, the content of organic carbon in samples of Hole $416 \mathrm{~A}$ is about 0.4 per cent.

The yield of alcohol-benzene bitumen is proportional to organic matter content; it varies from $21 \mathrm{ppm}$ (Section $416 \mathrm{~A}-40-3$ ) to $850 \mathrm{ppm}$ (Section $415 \mathrm{~A}-8-1$ ). The bitumen coefficient (ratio of bitumen concentration to organic-carbon content, expressed as per cent) is often used as an in'dicator of the degree of organic matter transformation. Its sensitivity, however, seems to be insufficient. The bitumen coefficient throughout stays at approximately 5 per cent, although other data indicate certain changes in the course of diagenesis and catagenesis.

Among bitumen components, the hydrocarbon fraction increases with depth (Figure 9). This tendency is 
TABLE 16

Visible-Light Absorption Spectra of Bitumen and Bitumen Fractions, Hole 416A

\begin{tabular}{|c|c|c|c|c|c|c|c|c|c|}
\hline $\begin{array}{c}\text { Sample } \\
\text { (interval in } \mathrm{cm} \text { ) }\end{array}$ & $\begin{array}{l}\text { Sub-Bottom } \\
\text { Depth } \\
\text { (m) }\end{array}$ & $\begin{array}{c}\text { Time-Stratigraphic } \\
\text { Unit }\end{array}$ & $\begin{array}{l}\text { Bitumen, or } \\
\text { Bitumen } \\
\text { Fraction }\end{array}$ & & $\begin{array}{r}\mathrm{Vi} \\
\text { Absor } \\
\end{array}$ & 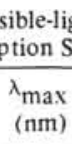 & $\begin{array}{l}\text { pectra } \\
\underline{\underline{p}}\end{array}$ & & Compounds \\
\hline \multirow{4}{*}{$\begin{array}{c}416 \mathrm{~A}-1-1,115-140 \\
2-2,56-74 \\
79-91\end{array}$} & $146.0-155.5$ & M. Miocene & Bitumen & 400 & 600 & 655 & & & Chlorins \\
\hline & $298.0-304.5$ & L. Miocene & Bitumen & 400 & 600 & 655 & & & Chlorins \\
\hline & & & $\begin{array}{l}\text { Benzene- } \\
\text { Methanol }\end{array}$ & 400 & 605 & 660 & & & Chlorins \\
\hline & & & Asphal tenes & 400 & 610 & 663 & & & Chlorins \\
\hline \multirow[t]{3}{*}{$3-3,60-87$} & $450.0-459.5$ & U. Oligocene & Bitumen & 400 & 600 & 655 & & & Chlorins \\
\hline & & & $\begin{array}{l}\text { Benzene- } \\
\text { Methanol }\end{array}$ & 400 & 600 & 650 & & & Chlorins \\
\hline & & & Asphaltenes & 400 & & 650 & & & Chlorins \\
\hline \multirow[t]{3}{*}{$6-3,29-75$} & $887.0-896.5$ & L. Aptian & Bitumen & 395 & & & & & Metalloporphyrins \\
\hline & & & $\begin{array}{l}\text { Benzene- } \\
\text { Methanol }\end{array}$ & 398 & 600 & & & & Chlorins \\
\hline & & & Asphaltenes & 400 & 600 & 650 & & & Chlorins \\
\hline $\begin{array}{c}7-2,36-47 \\
48-69 \\
9-3,114-117\end{array}$ & $991.5-1093.0$ & Hauterivian & Bitumen & $\begin{array}{c}398 \\
(400)\end{array}$ & & & & & Metalloporphy rins \\
\hline $\begin{array}{l}119-134 \\
139-143\end{array}$ & $1176.9-1185.4$ & Hauterivian & Bitumen & 395 & & & & & Metalloporphyrins \\
\hline \multirow{4}{*}{$11-4,61-81$} & $1194.8-1204.3$ & Hauterivian & Bitumen & 398 & & & & & Metalloporphyrins \\
\hline & & & Hexane & 385 & 408 & 428 & 435 & & $\begin{array}{l}\text { Polycyclic aromatics } \\
\text { (perylene type) }\end{array}$ \\
\hline & & & $\begin{array}{l}\text { Hexane- } \\
\text { Benzene }\end{array}$ & 395 & & & & & Metalloporphyrins \\
\hline & & & Asphaltenes & $\begin{array}{c}400 \\
(402)\end{array}$ & & 600 & & & Chlorins \\
\hline \multirow[t]{3}{*}{$13-2,79-109$} & $1213.8-1222.4$ & Hauterivian & Bitumen & 395 & & & & & Metalloporphyrins \\
\hline & & & Hexane & 385 & 410 & 435 & & & Poly cyclic aromatics \\
\hline & & & $\begin{array}{l}\text { Hexane- } \\
\text { Benzene }\end{array}$ & 395 & 515 & 552 & & & $\begin{array}{l}\text { Nickel porphyrins } \\
\text { (DPEP, etio types) }\end{array}$ \\
\hline \multirow{6}{*}{$\begin{array}{r}15-1,64-100 \\
104-111 \\
143-150\end{array}$} & & & & & & & & & \\
\hline & $1232.9-1242.5$ & Valanginian & Bitumen & 395 & & & & & Metalloporphyrins \\
\hline & & & Hexane & 360 & 382 & 408 & 428 & 435 & $\begin{array}{l}\text { Polycyclic aromatics } \\
\text { (perylene type) }\end{array}$ \\
\hline & & & $\begin{array}{l}\text { Hexane- } \\
\text { Benzene }\end{array}$ & 395 & 515 & 553 & & & $\begin{array}{l}\text { Nickel porphyrins } \\
\text { (DPEP, etio types) }\end{array}$ \\
\hline & & & $\begin{array}{l}\text { Benzene- } \\
\text { Methanol }\end{array}$ & 405 & 600 & & & & Chlorins \\
\hline & & & Asphaltenes & 400 & & & & & \\
\hline \multirow[t]{2}{*}{$20-2,0-50$} & $1277.5-1287.0$ & Valanginian & Bitumen & 392 & 555 & & & & Nickel porphyrins \\
\hline & & & $\begin{array}{l}\text { Hexane- } \\
\text { Benzene }\end{array}$ & 395 & 515 & 555 & & & $\begin{array}{l}\text { Nickel porphyrins } \\
\text { (DPEP, etio types) }\end{array}$ \\
\hline \multirow[t]{4}{*}{$22-3,68-86$} & $1299.5-1309.1$ & Valanginian & Bitumen & 392 & 550 & & & & Nickel porphyrins \\
\hline & & & Hexane & 380 & 408 & 435 & & & Polycyclic aromatics \\
\hline & & & $\begin{array}{l}\text { Hexane- } \\
\text { Benzene }\end{array}$ & 395 & 515 & 552 & & & $\begin{array}{l}\text { Nickel porphyrins } \\
\text { (DPEP, etio types) }\end{array}$ \\
\hline & & & Benzene & 398 & 515 & 552 & 585 & & $\begin{array}{l}\text { Nickel porphyrins } \\
\text { (DPEP, etio, } \\
\text { rhodo types) }\end{array}$ \\
\hline \multirow[t]{4}{*}{$25-1,6-60$} & $1327.7-1336.7$ & Valanginian & Bitumen $^{a}$ & 410 & 635 & 660 & & & Chlorins \\
\hline & & & & 510 & 550 & 580 & & & $\begin{array}{l}\text { Nickel porphyrins } \\
\text { (DPEP, etio, } \\
\text { rhodo types) }\end{array}$ \\
\hline & & & Hexane & 380 & 435 & & & & Polycyclic aromatics \\
\hline & & & $\begin{array}{l}\text { Hexane- } \\
\text { Benzene }\end{array}$ & 395 & 515 & 552 & & & $\begin{array}{l}\text { Nickel porphyrins } \\
\text { (DPEP, etio types) }\end{array}$ \\
\hline \multirow[t]{3}{*}{$27-1,68-118$} & $1346.7-1356.2$ & Valanginian & Bitumen & 395 & & & & & Metalloporphyrins \\
\hline & & & Hexane & 435 & & & & & Polycyclic aromatics \\
\hline & & & $\begin{array}{l}\text { Hexane- } \\
\text { Benzene }\end{array}$ & 395 & 515 & 553 & & & $\begin{array}{l}\text { Nickel porphyrins } \\
\text { (DPEP, etio types) }\end{array}$ \\
\hline \multirow[t]{4}{*}{$29-2,10-40$} & $1365.7-1375.2$ & Valanginian & Bitumen & 390 & 550 & & & & Nickel porphyrins \\
\hline & & & Hexane & 380 & 408 & 440 & & & Polycyclic aromatics \\
\hline & & & $\begin{array}{l}\text { Hexane- } \\
\text { Benzene }\end{array}$ & 395 & 515 & 553 & & & $\begin{array}{l}\text { Nickel porphyrins } \\
\text { (DPEP, etio types) }\end{array}$ \\
\hline & & & $\begin{array}{l}\text { Benzene- } \\
\text { Methanol }\end{array}$ & 395 & 555 & & & & Nickel porphyrins \\
\hline $31-2,32-74$ & $1384.6-1394.1$ & Valanginian & Bitumen & 395 & 955 & & & & Nickel porphyrins \\
\hline $40-3,95-125$ & $1454.5-1463.9$ & Valanginian & Bitumen & 395 & 550 & & & & Nickel porphyrins \\
\hline $44-2,57-91$ & $1491.5-1501.2$ & Valanginian & Bitumen & 395 & & & & & Metalloporphyrins \\
\hline $47-2,108-150$ & $1520.0-1529.5$ & Valanginian & Bitumen & 395 & & & & & Metalloporphy rins \\
\hline $50-2,31-81$ & $1548.6-1558.0$ & Berriasian & Bitumen & 392 & & & & & Metalloporphyrins \\
\hline
\end{tabular}

${ }^{a}$ Bitumen extracted during additional 72 hours. 


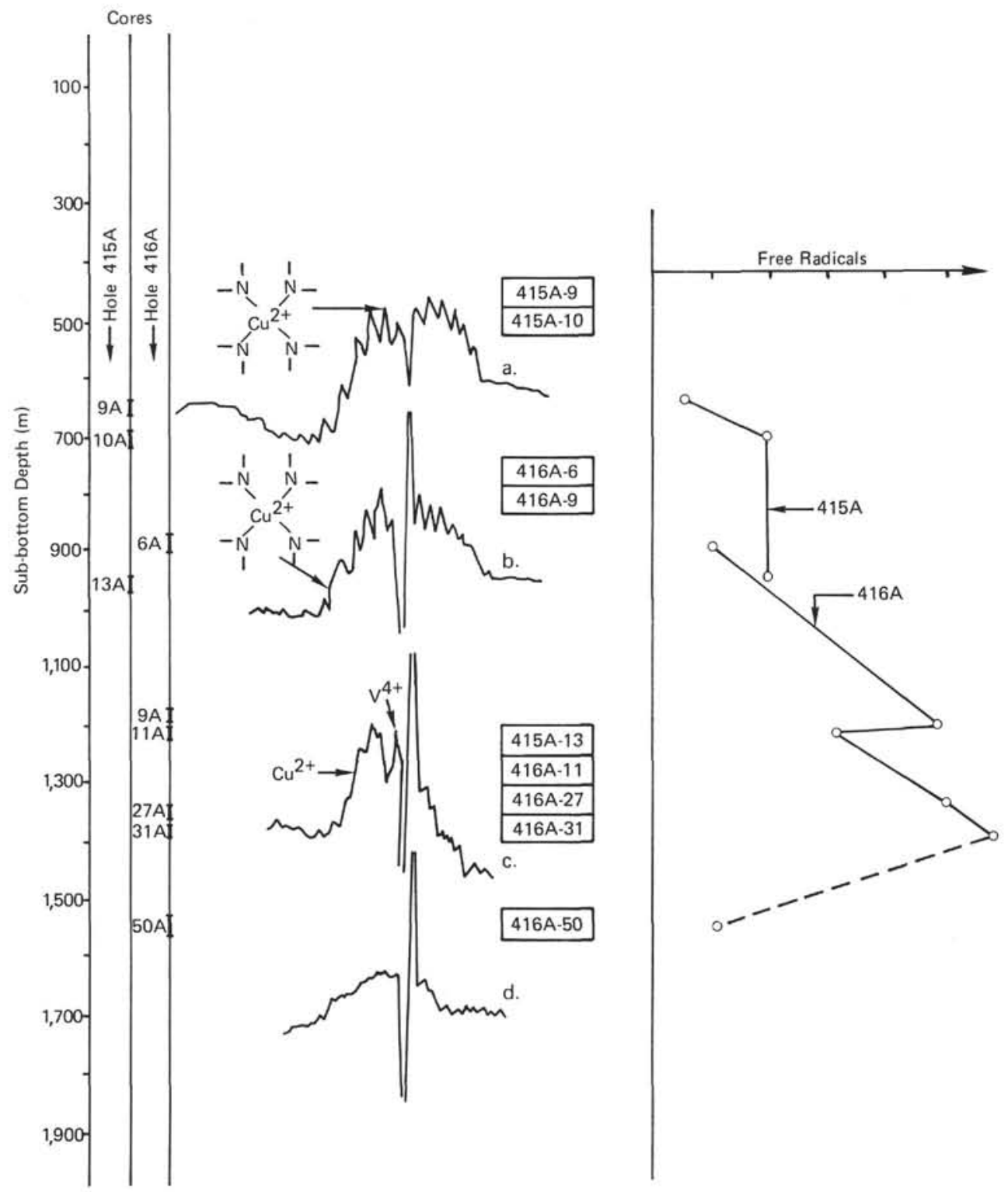

Figure 4. ESR spectra of bitumen from samples of the indicated cores, Sites 415 and 416.

revealed even more clearly when the amounts of polar and nonpolar bitumen components are compared (Figure 10).

In the lowest sample, which represents the most deeply buried sediments, the concentration of hydrocarbons reaches 25 per cent of total bitumen, and the combined contents of hydrocarbons and low-polarity resins exceeds 50 per cent, which can be regarded as an indication of sufficient maturity of organic matter in these deposits to generate oil hydrocarbons.

In the IR spectra of samples from Sections 416A-47-2 (depth 1520-1529.5 m) and 416A-50-2 (depth 1548.6$1558 \mathrm{~m}$ ), the $720-\mathrm{cm}^{-1}$ absorption band, corresponding to long aliphatic chains, becomes clearly defined (Figure 6).

The relative amounts of odd- and even-number normal alkanes does not show any systematic variation with depth (Figure 11). In the hydrocarbon fraction of the deepest sample, however, the ratio is equalized. The CPI coefficient is 1.3 , which is close to CPI coefficients for oils.

The complete absence of organic compounds extractable with alkali in samples from Hole $416 \mathrm{~A}$ below a depth of 1384 meters is significant (Table 4). This indicates complete inclusion of humic substances in the kerogen structure, that is, completion of kerogen formation at these depths.

The ratio of pristane to phytane is also considered to be one of the indicators of the degree of organic-matter transformation.

On the whole, the pristane-phytane ratio does increase with depth (Figure 12). In the profile of Hole 416A, a rather close correlation is established between the ratio of isoprenoids and the ratio of nonpolar to 

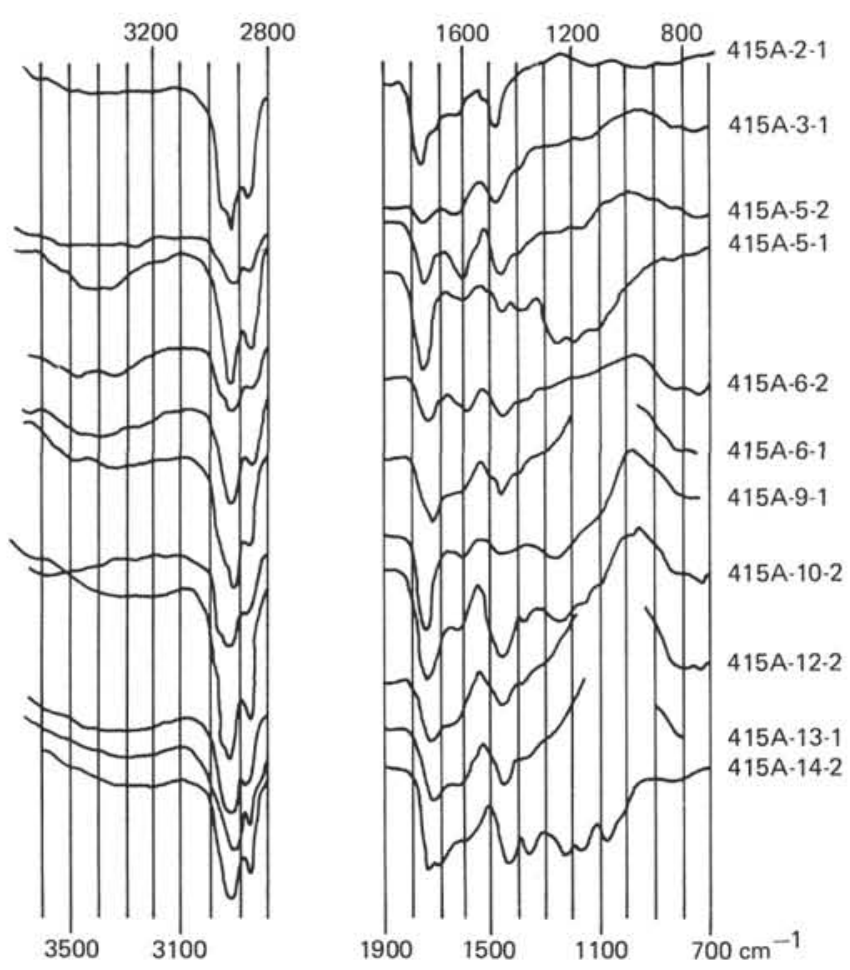

Figure 5. IR spectra of bitumen from samples of the indicated sections, Site 415.

polar bitumen fractions, which may indicate that both these parameters are, in this case, a function of the degree of organic-matter transformation (Figure 13). However, in the organic matter from the lowermost sample, which, judging by other data, is the most highly transformed, the pristane-phytane ratio is low. This may be caused by sediment diagenesis under relatively reducing conditions. It should also be noted that the total content of isoprenoid hydrocarbons is minimal in this sample (Table 7).

Evidently, the pristane-phytane ratio depends in a complicated way on the nature of initial substances, conditions of diagenesis, and degree of organic-matter transformation. It is obvious that in most cases phytane and pristane in the sediments originate from one and the same biological precursor-the phytol of chlorophyll. Their mechanism of formation is, however, different. As shown by experimental studies (Ikan et al., 1975), phytane can be formed by direct reduction of phytol, whereas pristane formation requires an intermediate stage of phytol oxidation to phytolic acid and subsequent decarboxylation. Thus, the chemistry of phytane and pristane formation seems to presuppose that the pristane-phytane ratio should be higher in sediments whose primary diagenesis occurred in a slightly oxidizing environment. Otherwise, one should expect lower pristane-phytane ratios.

It is probable that the ratio $\left(n-\mathrm{C}_{25}+n-\mathrm{C}_{27}\right) /\left(n-\mathrm{C}_{29}+\right.$ $n-\mathrm{C}_{31}$ ) can, to a certain extent, serve as an indicator of organic-matter transformation. This ratio tends to increase with depth (Table 8), and there is a certain cor-
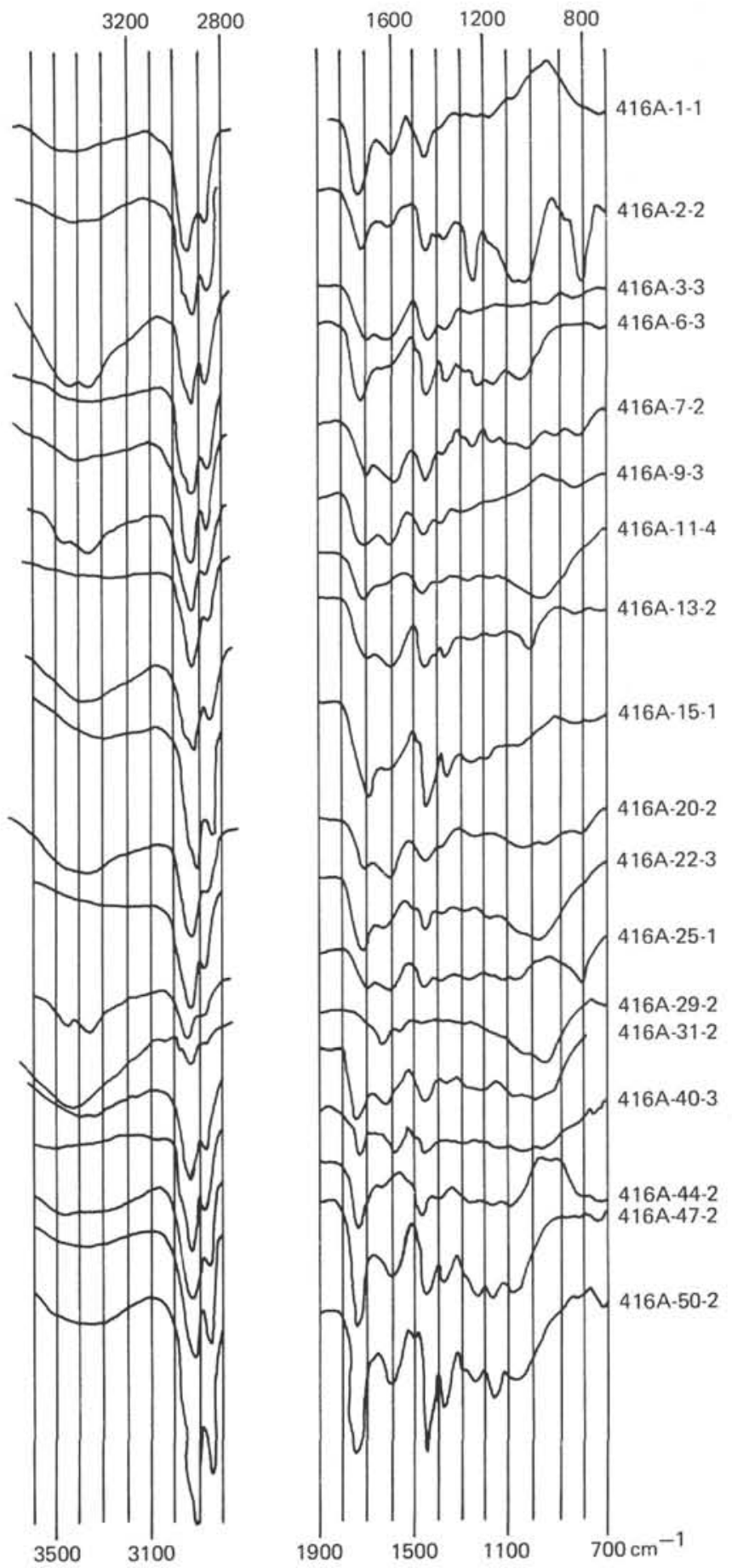

Figure 6. IR spectra of bitumen from samples of the indicated sections, Site 416.

relation between this parameter and the pristane-phytane ratio for the sediments of Hole 416A (Figure 14).

Analysis of visible-light and ESR spectra shows that the structure of pigments changes with depth. In the upper part of the profiles at Sites 415 and 416 , only chlorins are recorded in the visible-light spectra, whereas at depths of about 400 meters in Hole $415 \mathrm{~A}$ and about 900 meters in Hole 416A (Figure 15) metal porphyrins appear. A rather extensive transition zone where chlorins coexist 

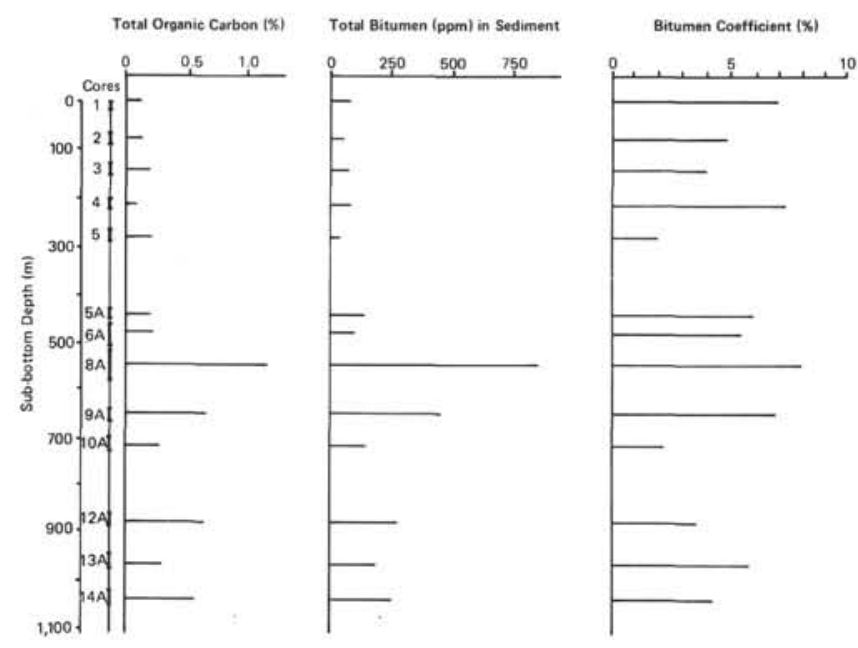

Figure 7. Organic carbon and bitumen in samples from Holes 415 and $415 \mathrm{~A}$.
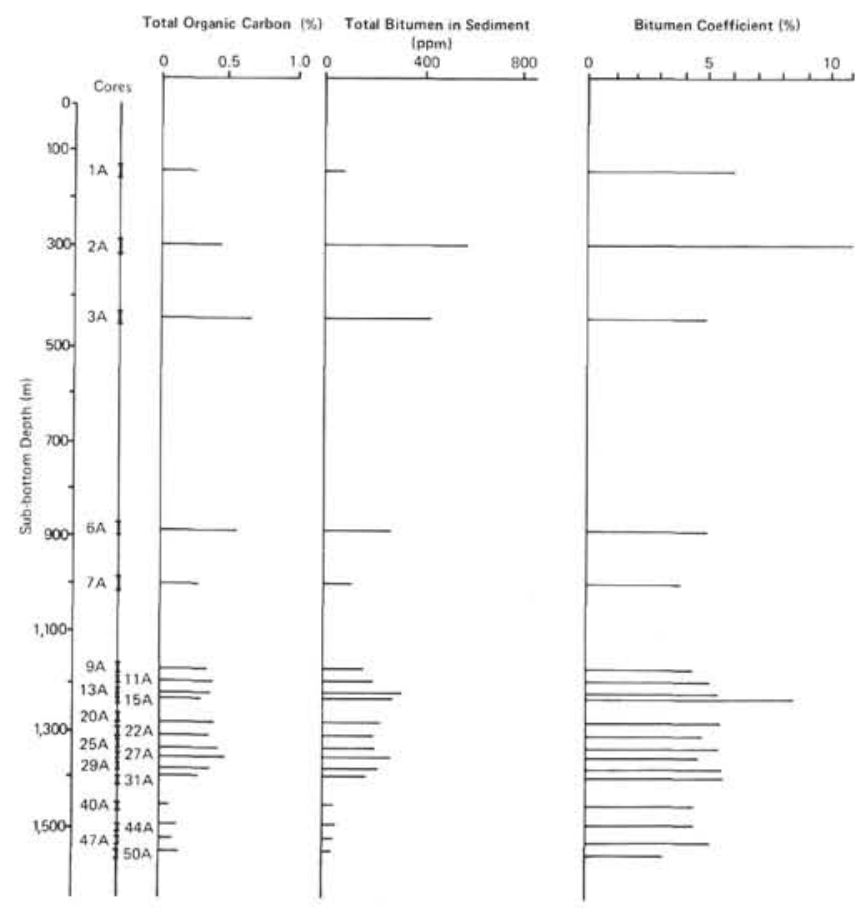

Figure 8. Organic carbon and bitumen in samples from Hole 416 A.

with metal porphyrins seems to exist. The visible-light spectra permitted identification of nickel porphyrins of the DPEP, etio, and rhodo types. In the ESR spectra, vanadyl porphyrins were identified at depths greater than 900 meters. In the upper sediments, ESR spectra indicate copper in chlorin complexes.

The concentration of stable radicals in organic matter increases with depth of burial. These radicals are concentrated in the high-molecular-weight bitumen components. The increase of stable radicals in the bitumen with depth seems to reflect progression of organic-matter transformation by the radical mechanism (Galimov, 1973, p. 203). Stable radicals are in this case inactive

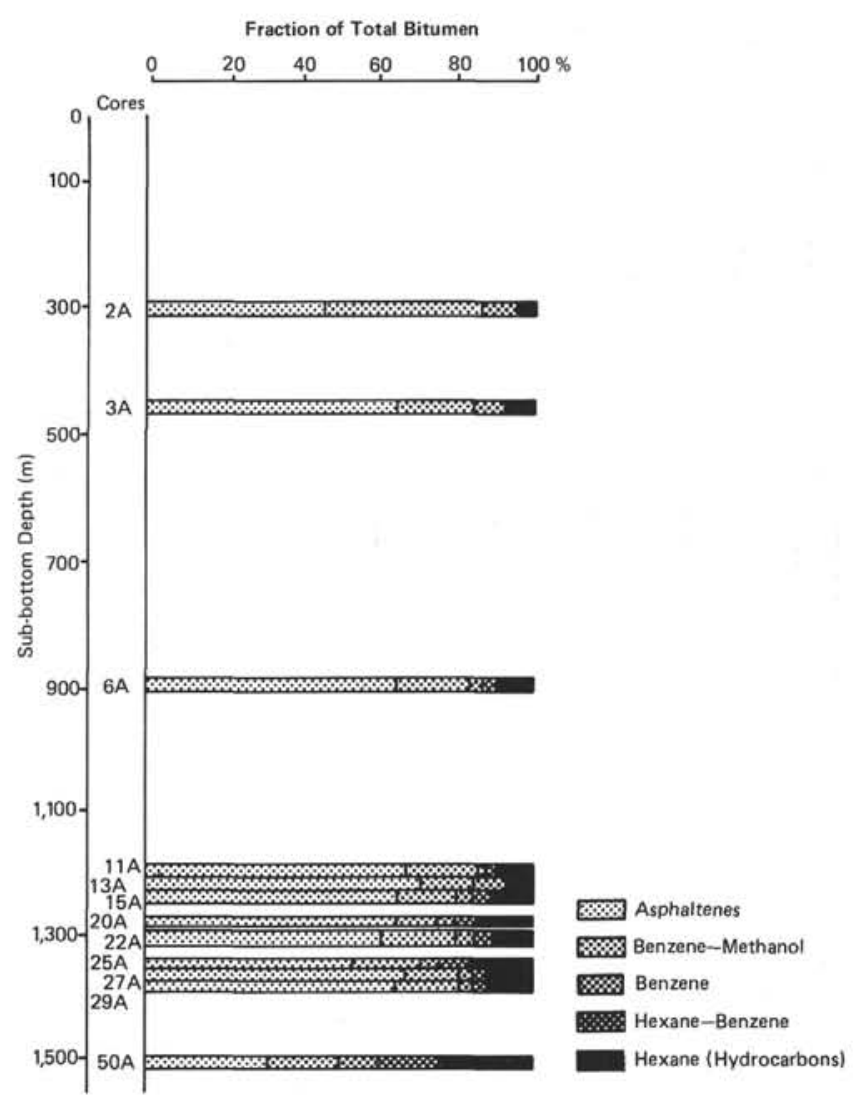

Figure 9. Bitumen components, Site 416.

and bonded with high-molecular-weight bitumen components; they result from organic-matter transformation by the radical mechanism. The small quantity of free radicals in the lowest sample (Figure 4) seems to be associated with a decrease in the carriers of free radicals-asphaltenes and polar resins-in the bitumen.

The transformation of chlorins into metal porphyrins and the successive substitution of nickel and vanadyl porphyrin complexes for copper porphyrin complexes in the course of the general transformation of organic matter is a characteristic path of evolution of pigments. This has been established previously for continental sedimentary sections (Chinyonov et al.,1975). It is to be noted that the observed structural changes in pigments take place at approximately constant depths.

On the question of sources of organic matter in the sediments, one first of all has to direct attention to analysis of isotopic data.

Of primary significance among the factors which determine the isotopic composition of carbon in fossil organic matter is whether the initial organic material is of terrestrial or marine origin.

The isotopic composition of marine plankton, depending on water temperature and isotopic composition of bicarbonate, usually varies from -19 to -22 per mill. Terrestrial organisms are, on the average, much richer in the light isotope, but the variation in their isotopic composition is greater $(-13$ to $-33 \%)$. aquatic plants is between -24 and -26 per mill. Therefore, organic-carbon isotopic composition can, in prin- 


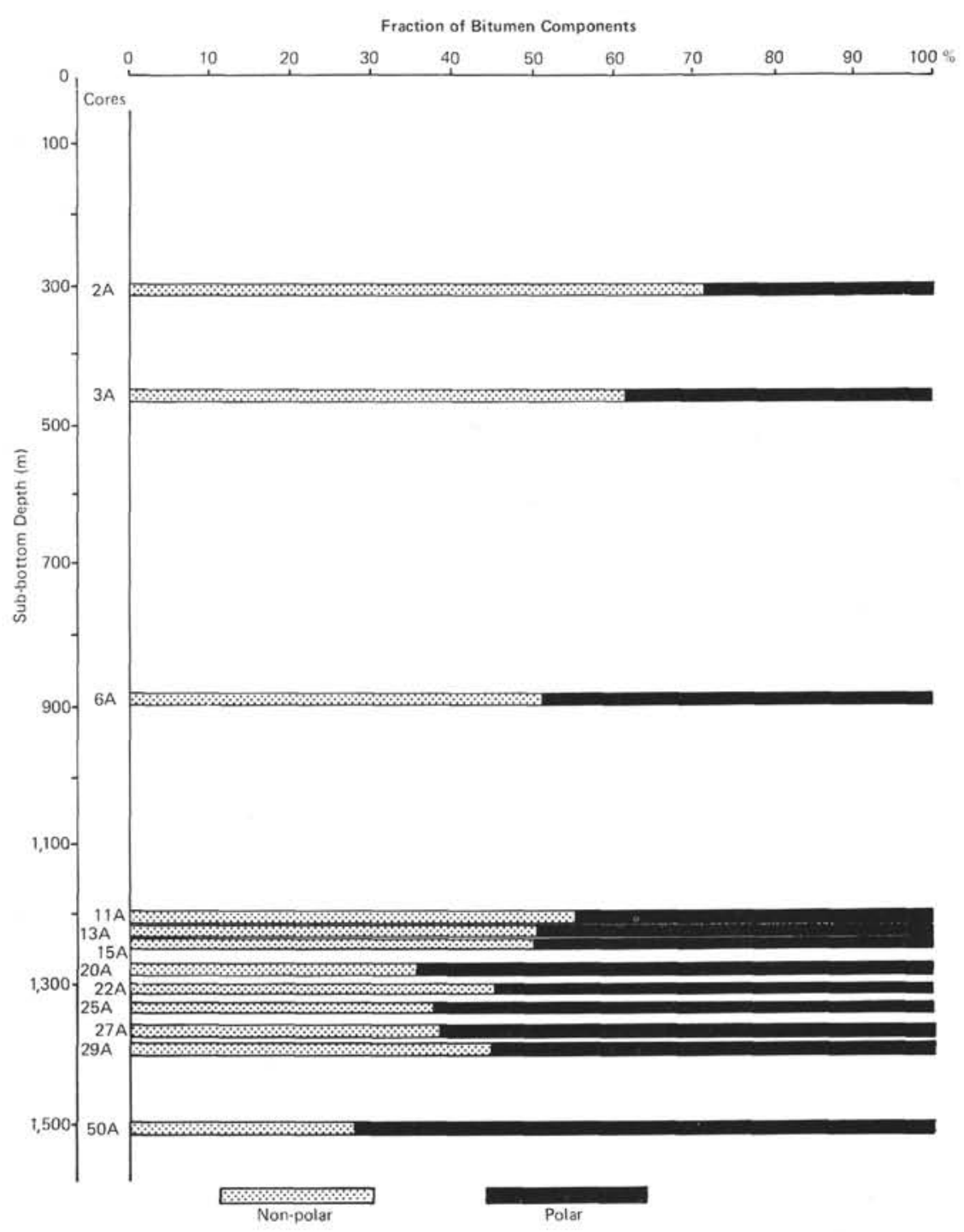

Figure 10. Polar and nonpolar bitumen components, Site 416.

ciple, serve as an indicator of the relative contribution made by materials of marine and continental origin.

In accordance with the data of organic-carbon isotopic analysis, the sediments penetrated by Holes 415 and $415 \mathrm{~A}$ can be roughly subdivided into two intervals (Figure 16), the boundary passing between Sections 415-5-2 (lower Miocene, depth $283 \mathrm{~m}$ ) and 415A-5-1 (upper Paleocene, depth $443 \mathrm{~m}$ ). Organic carbon of the upper interval is characterized by $\delta^{13} \mathrm{C}$ values of -22.3 to -23.8 per mill. In the lower interval, organic carbon is enriched in the ${ }^{12} \mathrm{C}$ isotope, and the $\delta^{13} \mathrm{C}$ values vary from -26.6 to 29.7 per mill.

In the sediments of Hole 416A, three intervals can be identified (Figure 17). In the upper interval, with the exception of the Pleistocene, organic carbon is characterized by relatively high $\delta^{13} \mathrm{C}$ values: -22.31 per mill (Section $416 \mathrm{~A}-2-2$ ) and -22.76 per mill (Section 416A-3-3). The boundary between the upper and the middle intervals passes between Sections 416A-3-3 (upper Oligocene, depth $459.5 \mathrm{~m}$ ) and 416A-6-3 (lower Ap- tian, depth $887 \mathrm{~m}$ ). The middle interval is characterized by organic carbon highly enriched in the light isotope. The $\delta^{13} \mathrm{C}$ values vary from -26.6 to -29.6 per mill, that is, within the same limits which characterize the lower interval of Site 415. From Section 416A-22-3 (depth $1309.1 \mathrm{~m}$ ) to Section 416A-25-1 (depth 1327.7 $\mathrm{m})$, within the Valanginian, the isotopic composition of organic carbon again changes sharply. The light isotope is depleted, although $\delta^{13} \mathrm{C}$ values are not as high as those of the upper interval; they vary from -25.3 to -26.6 per mill, that is, they are intermediate with respect to the $\delta^{13} \mathrm{C}$ values which characterize organic matter in the upper and the middle intervals.

If we now turn to the lithologic description of the sediments (site chapter, this volume), a good correlation will be seen between the distribution of isotopic compositions and facies, based on mineralogical composition and microfauna.

At Site 415 , the lower interval with isotopically light organic matter is made up of turbidites that have rede- 

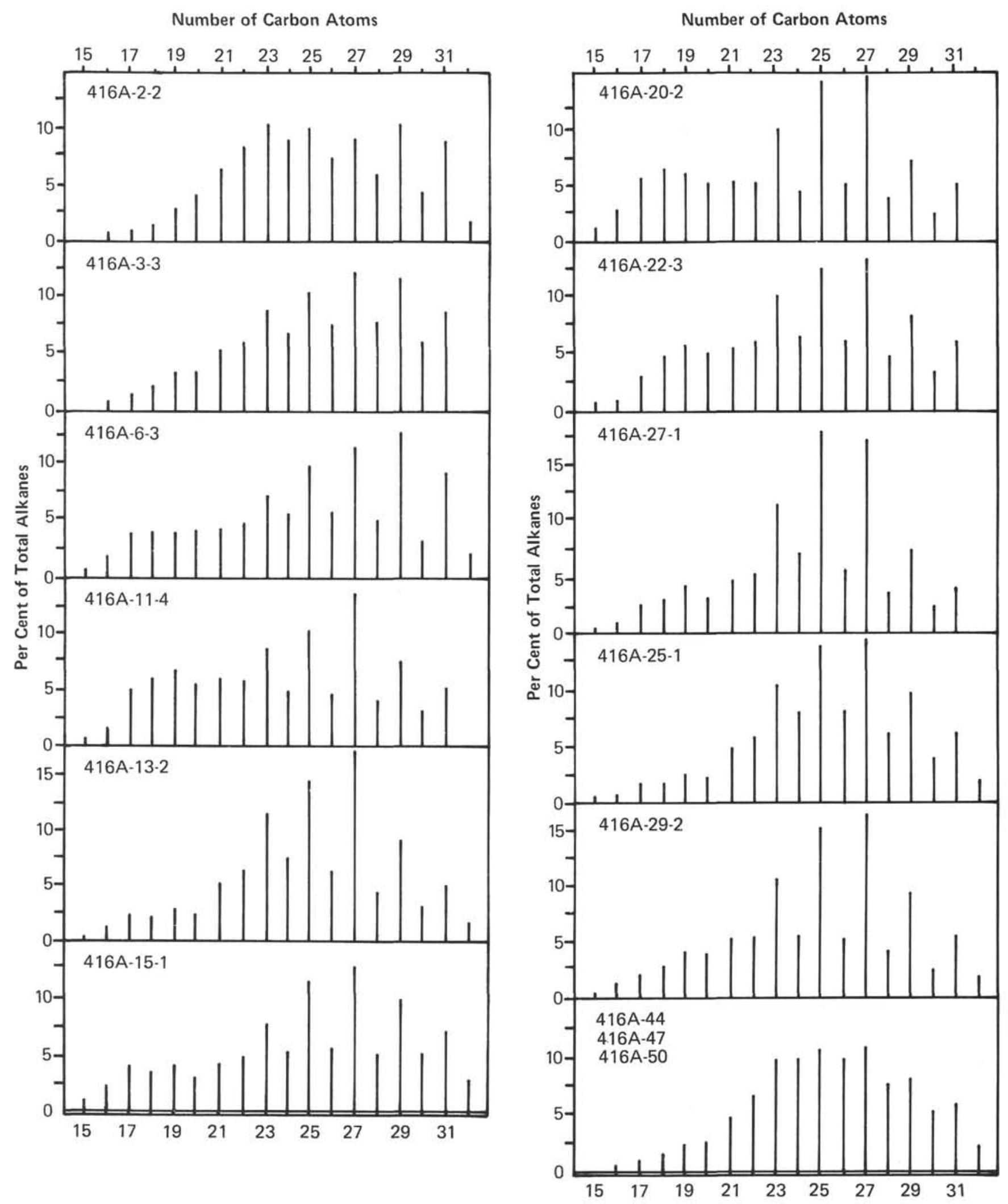

Figure 11. Distribution of n-alkanes. 


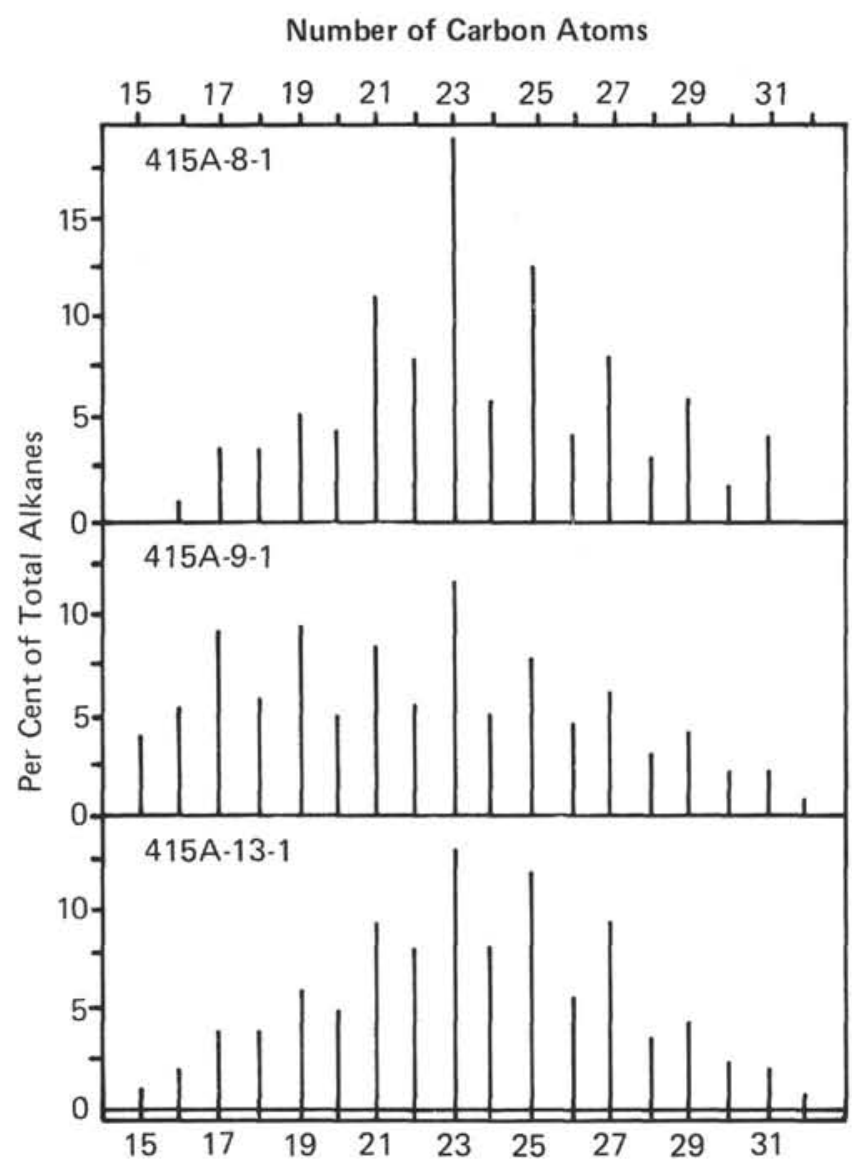

Figure 11. Continued.

posited terrigenous material from the continental shelf and slope. The upper interval is mainly pelagic or hemipelagic silts and muds.

At Site 416, the Upper Jurassic and Berriasian are approximately one third autochthonous, oceanic sediments and two thirds terrigenous material of turbidites. In the isotopically identified middle interval, the sediments are predominantly turbidites with terrigenous material. Finally, in the upper interval, as at Site 415, hemipelagic sediments predominate; this sedimentation regime began between the early Aptian and late Oligocene.

It should be noted that organic matter can be also relatively rich in the light isotope when the water temperature is low where the organisms developed (Rodgers et al., 1972). This dependence is, however, such that the intramolecular isotopic effects must simultaneously increase; therefore, the differences in isotopic composition of individual components must also increase (Galimov and Shirinsky, 1975). In other words, the intercomponent dispersion of isotopic compositions must increase. Greater dispersion in isotopic compositions in fossil-organic-matter components would then have to be expected in those samples where organic matter on the whole has a light isotopic composition. The dispersion in isotopic compositions of bitumen fractions indicated

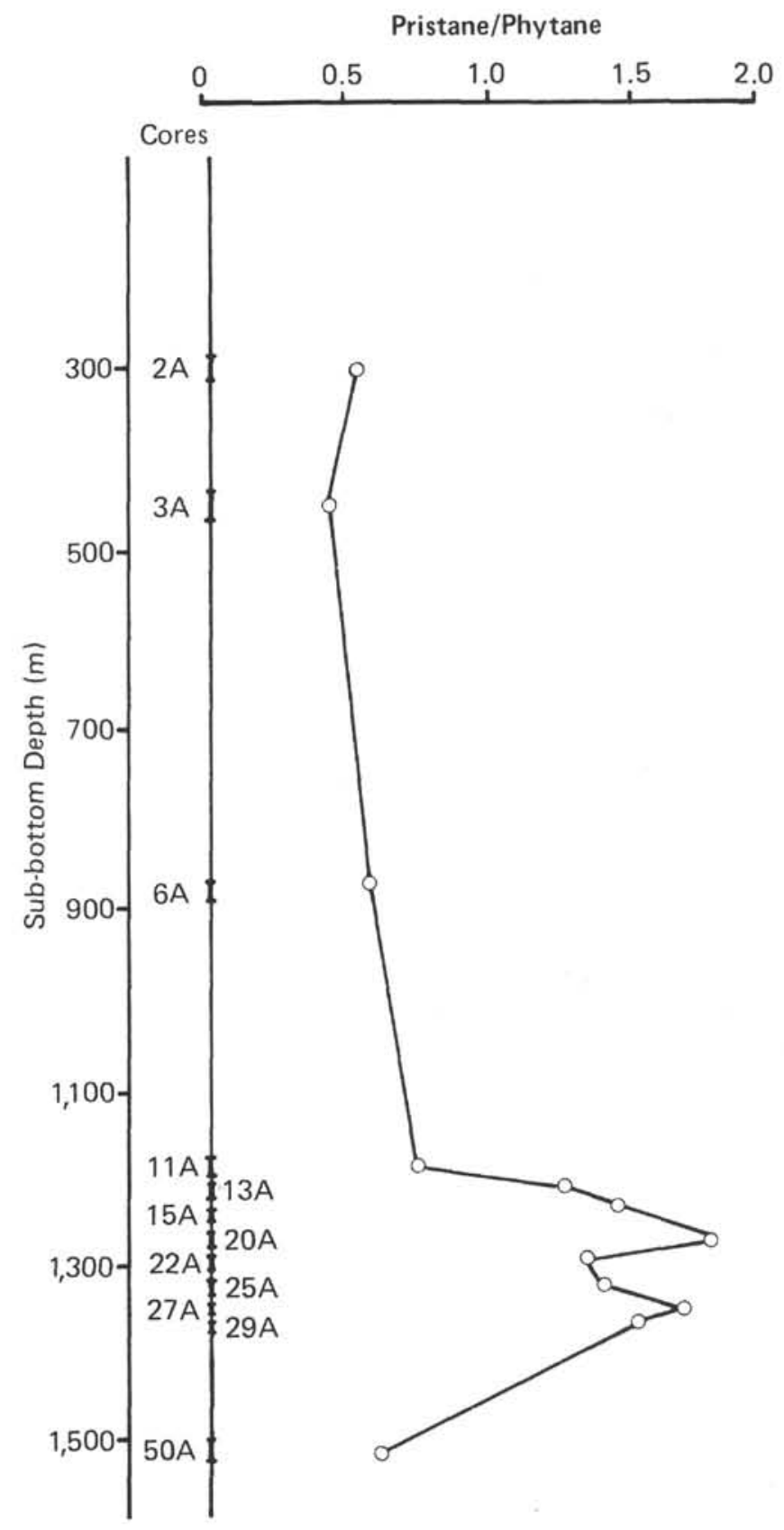

Figure 12. Variation in the pristane-phytane ratio with depth, Site 416.

by Table 12 shows that there is no such tendency. On the contrary, an opposite relationship is observed. This, along with the fact that isotopic zonality is in good agreement with the abundance of turbidites in certain geological periods, is convincing evidence that the enrichment of organic matter in the light isotope in the aforementioned intervals is indeep associated with the continental source of this matter. Therefore, the isotopic composition of organic carbon in the sediment in this case can be regarded as a measure of the contribution of terrigenous material to its formation. 


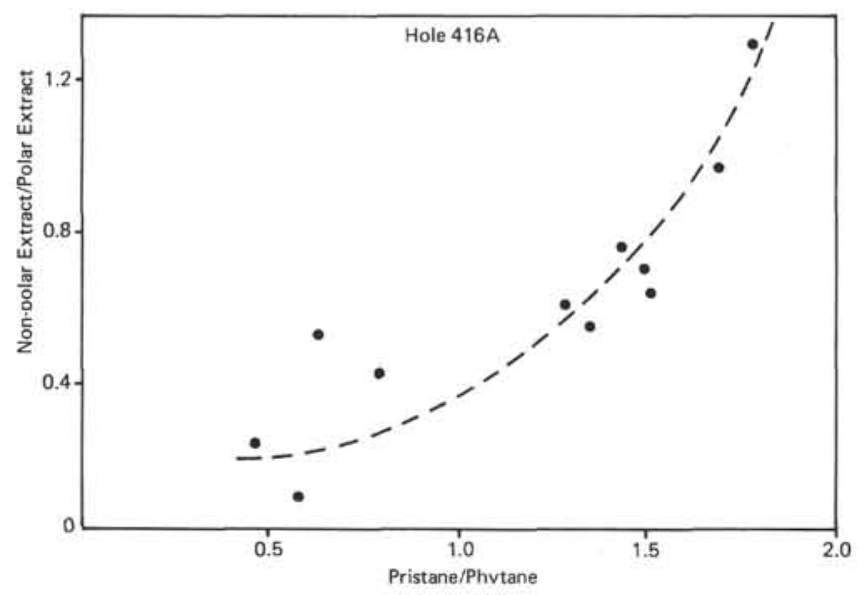

Figure 13. Variation in the ratio of nonpolar to polar bitumen extracts as a function of the pristanephytane ratio, Site 416 .

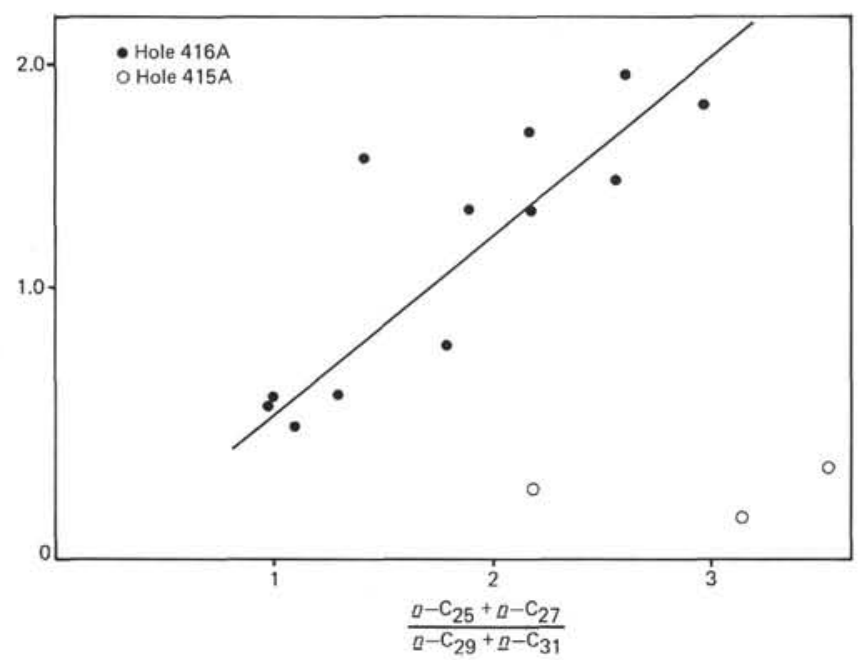

Figure 14. Pristane/Phytane ratio versus $C_{25}+C_{27} /$ $C_{29}+C_{31}$ ratio. Variation in the pristane-phytane ratio as a function of the ratio $\left(C_{25}+C_{27}\right) /\left(C_{29}+C_{31}\right)$, Sites 415 and 416.

A number of observations, however, correlate poorly, at least at first sight, with this zonality in the distribution of marine and continental organic matter.

The predominance of odd-number normal alkanes in the investigated sediments is, on the whole, in agreement with the concept of a continental origin of a certain organic-material fraction in the sediments. The CPI coefficient, however, does not have higher values in the intervals where, according to isotopic data, the contribution of terrigenous organic matter is especially great.

The distribution of odd-number normal alkanes is also surprising: it is bimodal, with maxima at $n-\mathrm{C}_{27}$ and $n-\mathrm{C}_{17}$ in samples enriched in continental material (Figure 11). The $n-\mathrm{C}_{17}$ alkane is considered to have originated mainly from marine plankton, whereas the abundance of the $n-\mathrm{C}_{27}$ alkane reflects an increased contribution of organic matter from higher plants.
Since terrestrial plants are enriched in the light isotope, one should have expected to observe a direct correlation between the ratio $n-\mathrm{C}_{27} / n-\mathrm{C}_{17}$ and the light-isotope content in the organic carbon of the sediment. The relationship actually observed is quite the reverse (Figure 18).

The distribution of humic acids is somewhat unusual. The quantity of humic acids is known to decrease with increasing organic-matter transformation. Being the intermediate products of the polymerization and polycondensation of primary organic structures, they finally pass into kerogen and disappear as independent fractions. In the sediments of Hole $416 \mathrm{~A}$, however, we observe humic acids in two intervals (Table 4); there is an interval within which no humic acids are manifest, although they should have been present, in consideration of the low degree of organic-matter transformation at these depths. This interval exactly corresponds to that which is characterized by an abundance of terrigenous turbidite material and low $\delta^{13} \mathrm{C}$ values for organic carbon. This seems strange, if we recall that it is precisely the organic matter of continental type that is very rich in humic acids.

Finally, the very isotopic-composition values which characterize the terrigenous carbon in the section are unusually low. Carbon of continental origin is enriched in the light isotope, and this fact is used as a reliable criterion to establish whether the organic matter in the deposits is predominantly marine or continental. However, the $\delta^{13} \mathrm{C}$ values of -28 to -30 per mill established for the bottom part of the profile of Hole 415A and the middle part of the profile of Hole 416A seem too small even for typical terrestrial plants. As noted, the isotopic composition of carbonized higher-plant fragments was studied in several samples. Their isotopic composition is characterized by $\delta^{13} \mathrm{C}$ values of -24 to -25 per mill. It should be noted that these very values are typical of terrestrial plants. Why then are the $\delta^{13} \mathrm{C}$ values of the dispersed organic matter of the sediments so low?

To explain these facts, we must assume that the composition of organic matter of continental origin in oceanic sediments probably does not conform to our traditional understanding.

Indeed, organic matter of continental origin transported to the ocean by turbidites is subjected to extremely intensive mechanical and chemical processing. As a result, only the most resistant ingredients can remain intact. Among these are wood fragments and spores and pollen.

Spores and pollen, having an essentially lipid composition, constitute the isotopically lightest component of terrestrial plant material. This could explain the unusual enrichment of the light isotope in organic matter of predominantly continental origin. Although the question needs a special study, it is possible that the lipid material of spores and pollen is the source of hydrocarbons with 17 carbon atoms.

The behavior of humic acids is also explainable from from this point of view. The primary humic acids evidently were lost in the course of transportation and redeposition, together with the other relatively unstable components; thus, in the organic matter enriched in 


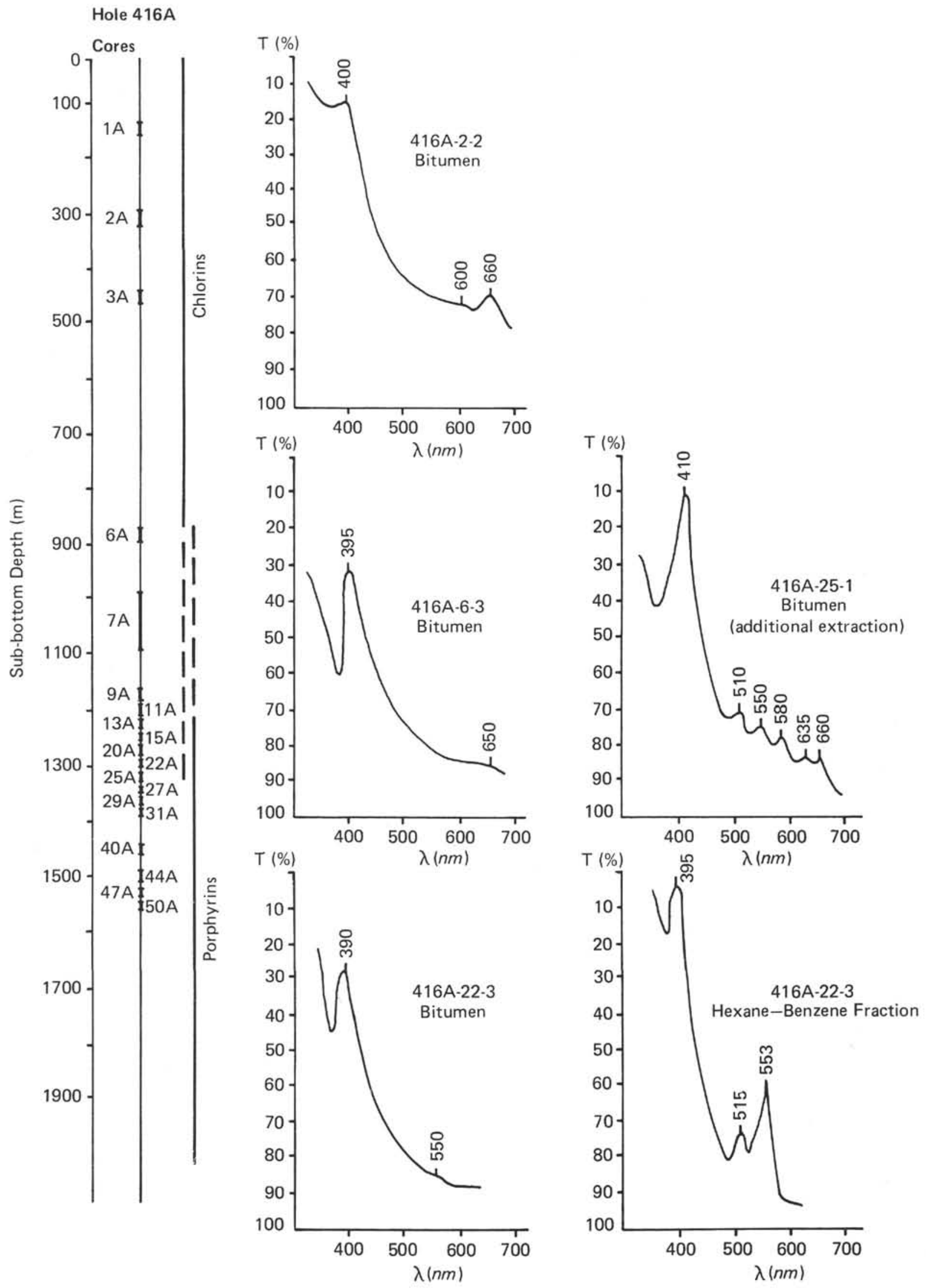

Figure 15. Change in tetrapyrrole structure with depth, in samples from the indicated section, Site 416. 


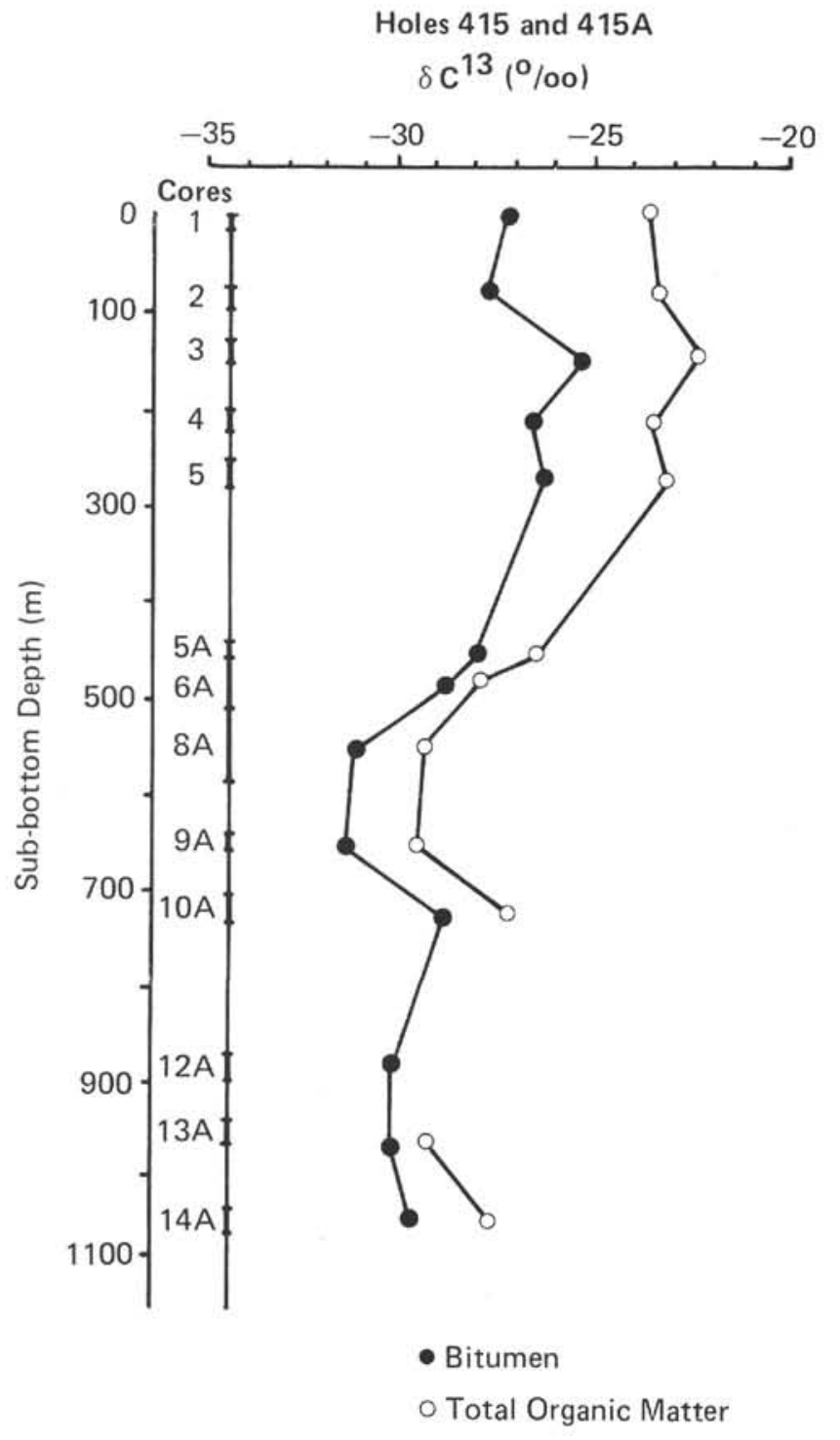

Figure 16. Variation in carbon-isotope composition of total organic matter and bitumen with depth, Site 415 .

spores and pollen they could no longer be formed in appreciable amounts.

Some other observations agree with this assumption, for example, the small dispersion of $\delta^{13} \mathrm{C}$ values in the bitumen components of continental organic carbon in the studied sediments. Both the fraction of spore and pollen material extractable with organic solvents and that unextractable are of lipoid composition and, with the general enrichment in the light isotope, should not have a noticeably different isotopic composition. As we have noted, polycyclic aromatics in the visible-light spectra of bitumens are observed only in that interval which is characterized by low $\delta^{13} \mathrm{C}$ values of organic carbon. Moreover, the most clearly expressed spectra of

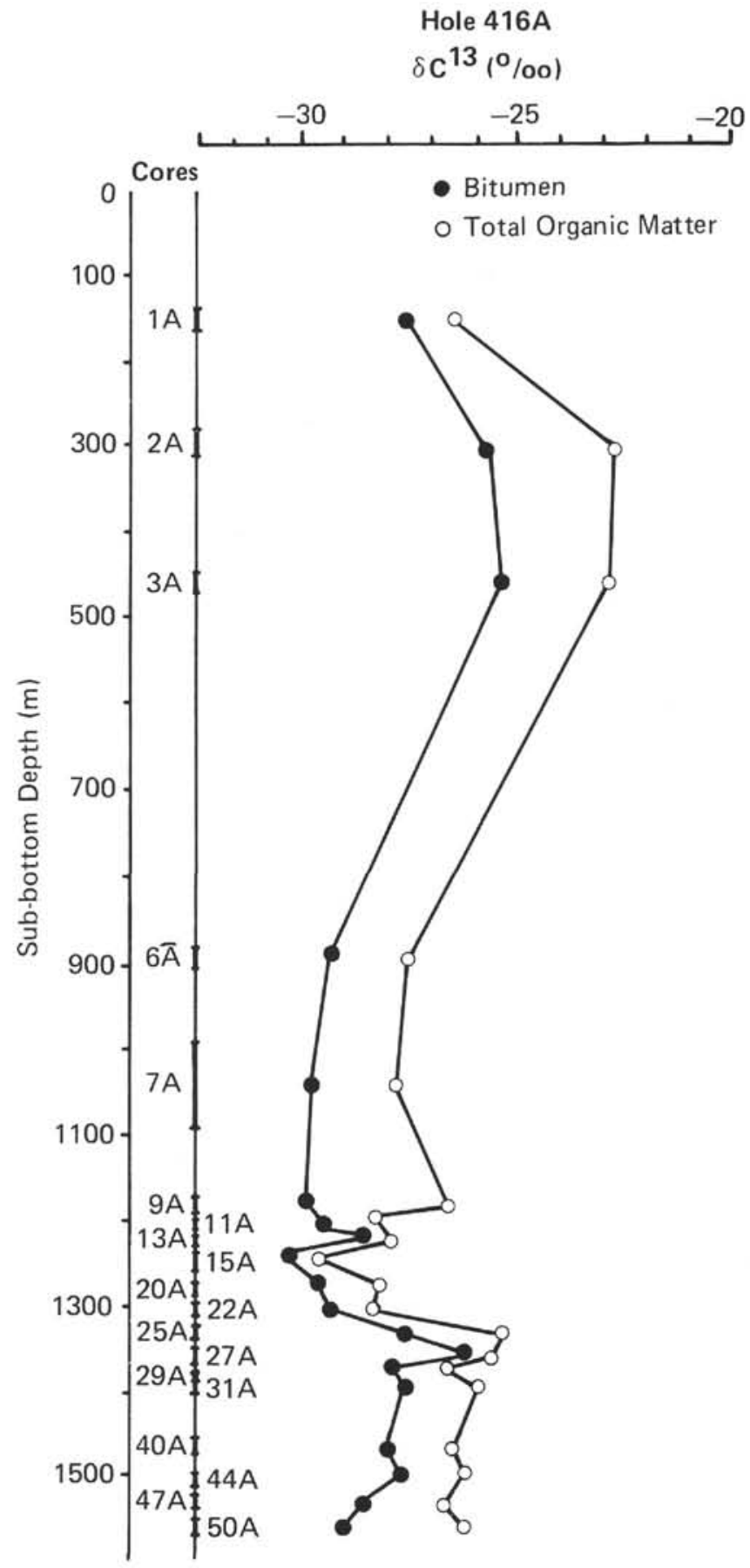

Figure 17. Variation in carbon-isotope composition of total organic matter and bitumen with depth, Site 416.

polycyclic aromatics of the perylene type were established for Sample 415A-8-1, 50-80 cm and Sample $416 \mathrm{~A}-15-1,64-150 \mathrm{~cm}$. Both these samples are characterized, for the sections investigated, by enrichment of both total organic matter and bitumen in the light isotope. This should be compared with the fact that 


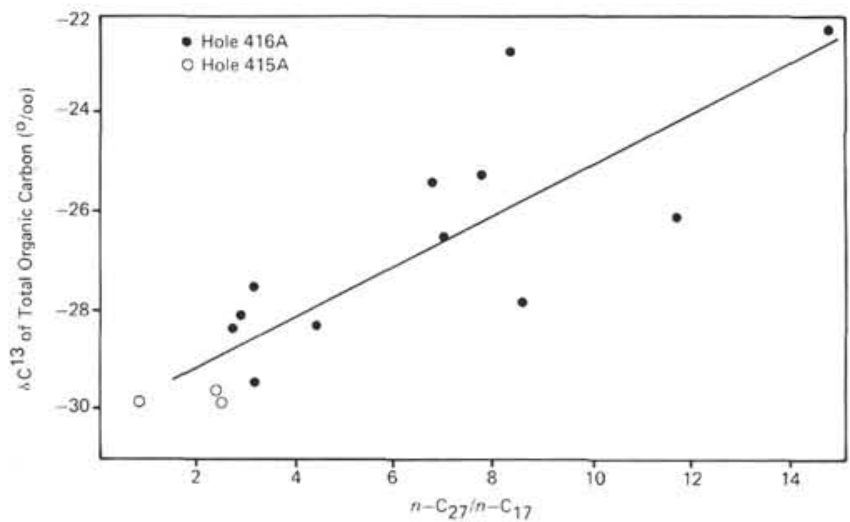

Figure 18. Variation in carbon-isotope composition of total organic matter as a function of the ratio $n-C_{27}$ / $\mathrm{n}-C_{17}$.

polyaromatic structures have been found experimentally in sporopollenine and products of its thermohydrolysis (Generalova et al., 1974).

It thus seems reasonable to believe that, in the sediments investigated, the organic material of continental origin is mainly represented by the spore and pollen material.

We shall also note some correlations which reveal certain genetic relationships among the components of organic matter in the investigated sediments.

Throughout the profiles of Holes $415,415 \mathrm{~A}$, and $416 \mathrm{~A}$, a correspondence of isotopic composition of total organic matter (practically kerogen) to that of bitumen is observed. From this it follows that bitumen is syngenetic with the total organic matter of the sediments; its presence is not a result of migration from an extraneous source.

The distribution of isotopes among different fractions is regular (Figure 19). The fractions most enriched in the light isotope are the hydrocarbons and low-polarity (hexane-benzene) resins. With increasing content of heteroatomic structures, the isotopic composition changes toward higher $\delta^{13} \mathrm{C}$ values. Asphaltenes and polar resins are, as a rule, the bitumen fractions poorest in the ${ }^{12} \mathrm{C}$ isotope. This distribution is in conformity with the concept of thermodynamically ordered distribution of carbon isotopes in biological systems (Galimov, 1973). It also shows that fossil-organic-matter components inherit the isotopic distribution inherent in the initial structures of biological precursors.

A correlation is observed among the isotopic compositions of bitumen fractions with one another and between these and the isotopic composition of organic matter of the sediment as a whole. It is noteworthy that correlation coefficients successively decrease when the $\delta^{13} \mathrm{C}$ value of total organic carbon is compared with that of asphaltenes, alcohol-benzene resins, benzene resins, hexane-benzene resins, and hydrocarbons; this evidently corresponds to their genetic remoteness from the initial matter (Figure 20).

Dispersion of $\delta^{13} \mathrm{C}$ values of hydrocarbons (Table 12 ), is much smaller than the dispersion of $\delta^{13} \mathrm{C}$ values

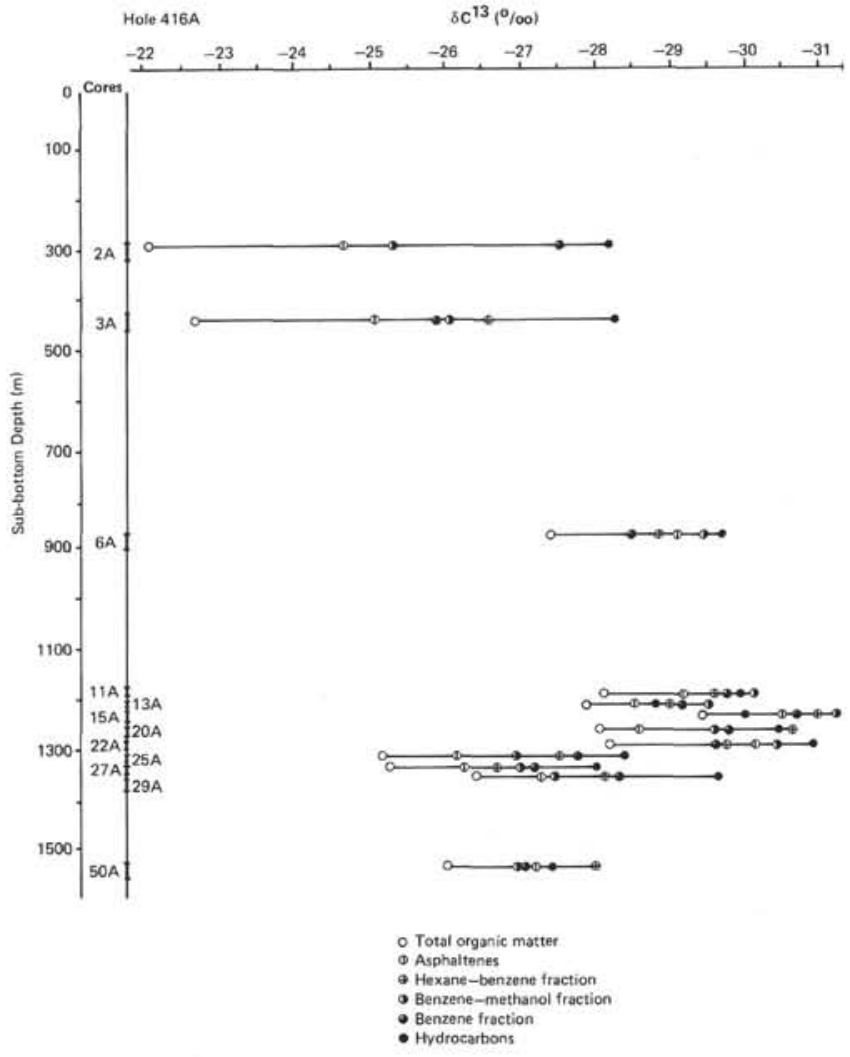

Figure 19. Carbon-isotope composition of bitumen fractions the total organic matter from samples of the indicated cores, Site 416.

for asphaltenes or alcohol-benzene resins. The structure and isotopic composition of the latter are much closer to those of the initial organic matter, and the dispersion of their $\delta^{13} \mathrm{C}$ values corresponds to that of the total organic carbon of the sediments. In hydrocarbons, however, isotopic differences are to a great extent smoothed out. From this, among other things, it follows that of the extract components asphaltenes are the best indicators of the nature of initial organic matter. The isotopic composition of hydrocarbons is much less indicative.

\section{CONCLUSIONS}

1. The content of organic matter in the investigated oceanic sediments of the Moroccan Basin amounts on the average to 0.4 to 0.5 per cent, which corresponds to the clark for organic carbon in the Phanerozoic sedimentary crust of continents.

2. Material of continental origin constitutes a considerable fraction of the organic matter in the sediments investigated. The contribution of terrigenous material was different during different periods of the geological history of the areas studied. Its increase is seen to be accompanied by increase in the light-isotope content in organic carbon. The corresponding intervals are, as a rule, represented by turbidites.

3. Analysis of the obtained data permits the assumption that organic matter transported from the continent by turbidity flows was subjected to a kind of physico- 

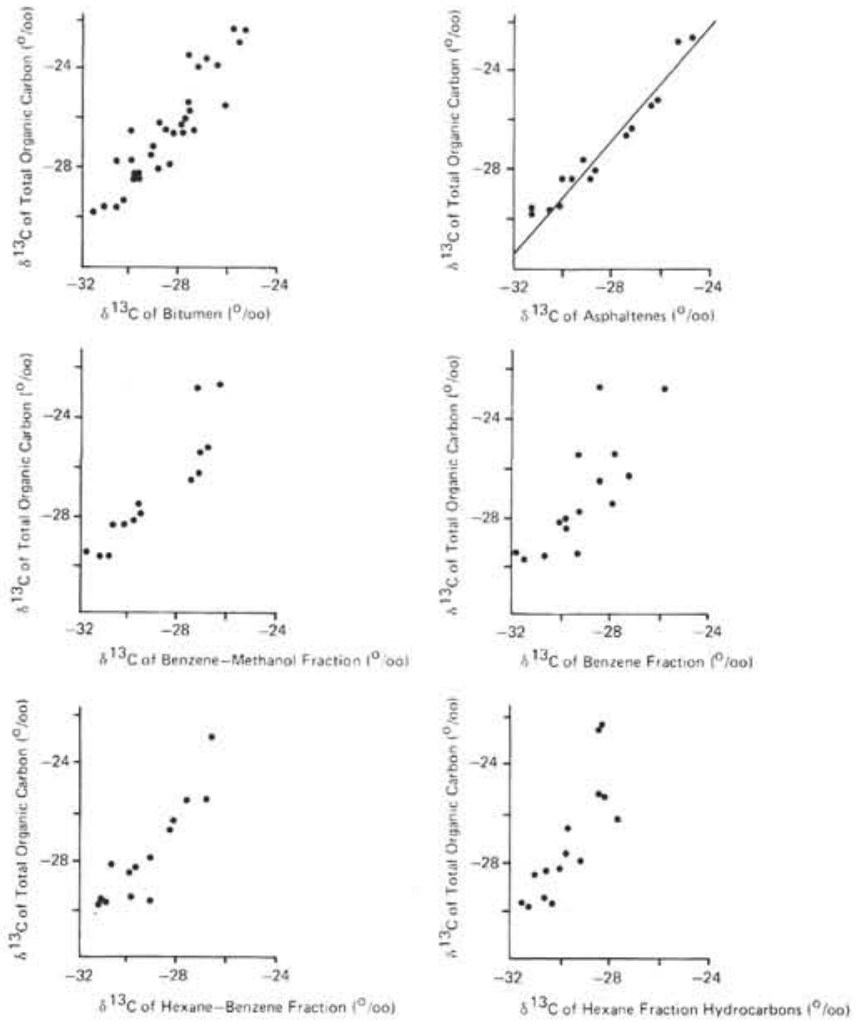

Figure 20. Variation in isotopic composition of total organic carbon as a function of carbon-isotope composition of bitumen fractions, Sites 415 and 416.

chemical fractionation, as a result of which it was enriched in spore and pollen material. If this preliminary conclusion is valid, the implication is that the dispersed organic material of continental origin in the oceanic sediments is predominantly lipoid. One of the properties of such organic matter is that it is by far a more likely precursor of petroleum hydrocarbons than the usual continental organic matter of the humus type.

4. Against the background of variations in organicmatter properties and composition caused by variation in sources and burial conditions, tendencies are observed which reflect organic-matter transformation in the course of diagenesis and catagenesis: (a) an increase with depth in the relative content of low-polarity components in the bitumen, in particular hydrocarbons; and (b) transition from chlorins to metal porphyrins.
5. The composite sample from Cores $416 \mathrm{~A}-44,47$, and 50, representing the deepest deposits, shows properties characteristic of the organic matter of oil source rocks: (a) a high content of hydrocarbons and lowpolarity components $(75 \%)$ in the bitumen; and (b) a low value of CPI, the distribution coefficient for normal alkanes.

This may indicate that at these depths of burial (1491.5-1558 m) organic matter enters the stage of formation of petroleum hydrocarbons.

6. The correspondence of isotopic compositions of total organic carbon to those of bitumen and its components, which was observed throughout, indicates that the hydrocarbons, along with the other mobile organicmatter fractions in the studied sediments, are autochthonous.

\section{ACKNOWLEDGMENTS}

The authors wish to express their gratitude to Dr. N. V. Lopatin and Dr. T. P. Emez for petrographic descriptions of the plant fragments, to Prof. A. V. Karjakin for providing IR spectra, and to Dr. A. V. Lebedev for helping in interpretation of the ESR spectra of bitumen.

\section{REFERENCES}

Chinyonov, V. A., Marov, I. N., Belyaeva, V. K., Drozdova, T. V., and Bogacheva, M. P., 1975. Study of vanadium and copper in bitumen of sedimentary rocks by ESR-spectroscopy. Geokhimiya, n.1, p. 112.

Galimov, E. M., 1973. Carbon Isotopes in Oil-Gas Geology: Moscow (Nedra), pp. 1-384.

Galimov, E. M. and Shirinsky, V. G., 1975. Ordered distribution of carbon isotopes in individual compounds and components of the lipid fraction of organisms, Geokhimiya, n. 4, p. 503.

Generalova, V. N., Kodina, L. A., Karjakin, A. V., and Petrova, I. W., 1974. On the nature of fossil sporopollenine, Geokhimiya, n. 6, p. 904.

Ikan, R., Baedecker, M. J., and Kaplan, I. R., 1975. Thermal alteration experiments on organic matter in recent marine sediment. II. Isoprenoids. Geochim. Cosmochim. Acta, v. 39, p. 187.

Rodgers, M. A., van Hinte, J. E., and Sugden, J. G., 1972. Organic carbon $\delta \mathrm{C}^{13}$ values from Cretaceous, Tertiary and Quaternary marine sequences in the North Atlantic. In Laughton, A. S., Berggren, W. A., et al., Initial Reports of the Deep Sea Drilling Project, v. 12: Washington (U.S. Government Printing Office), pp. 1115-1126. 

PLATE 1

Amber and plant fragments, Hole 416A.

(Unless otherwise indicated, magnifications are $125 \times$.)

Figure 1 Amber grains, Sample 416A-16-2, 91-92 cm $(6 \times)$.

Figure 2 Fragment of plant tissue, Sample 416A-16-2, 91$92 \mathrm{~cm}$

Figure 3 Fragment of plant tissue with cuticula, Sample 416A-23-2, 98-101 cm.

Figure 4 Fragment of wood tissue, Sample 416A-24-2, 58$59 \mathrm{~cm}$.

Figure 5 Homogeneous coalified plant tissue, Sample 416A$24-2,62-63 \mathrm{~cm}$. 


\section{PLATE 1}

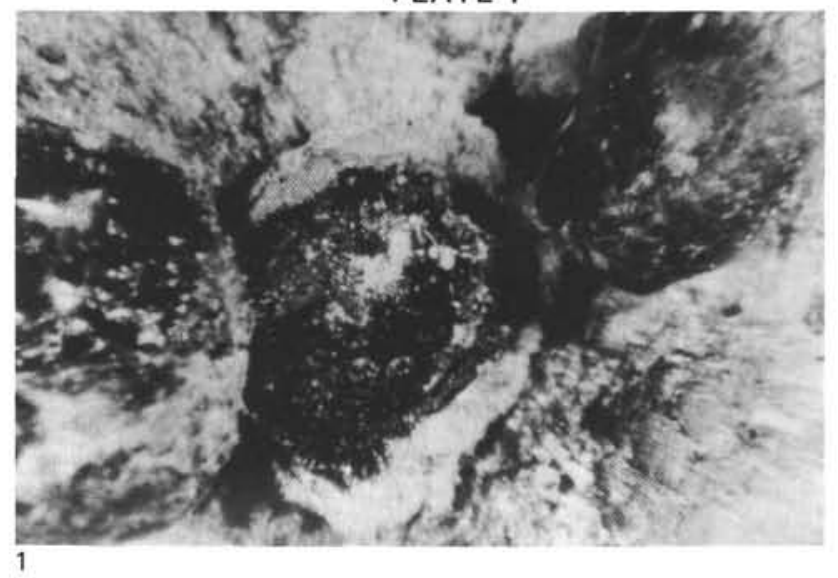

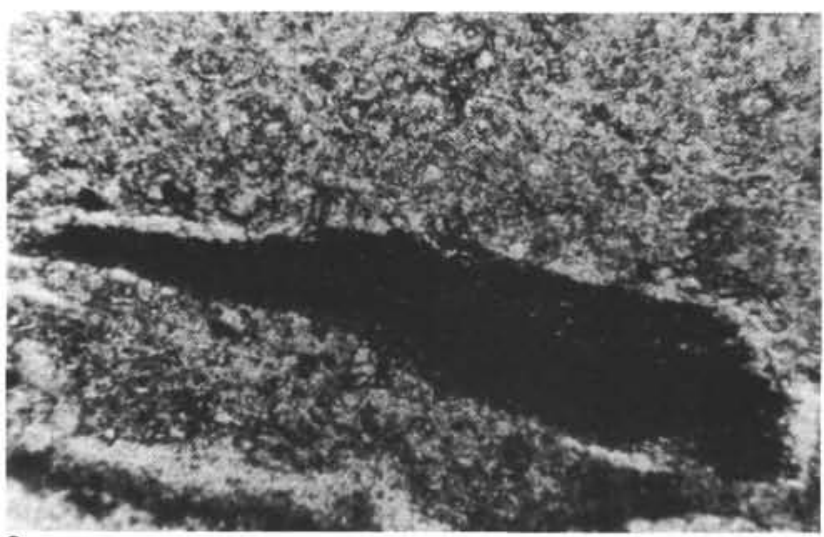

2

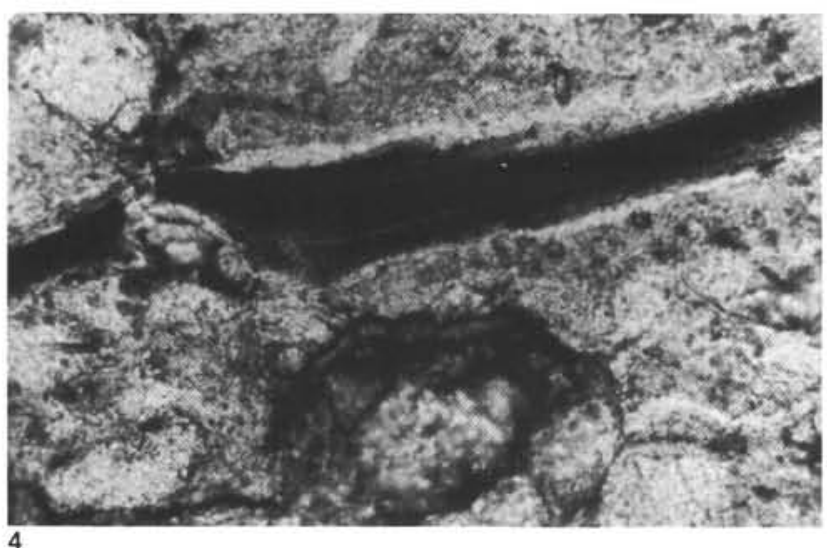

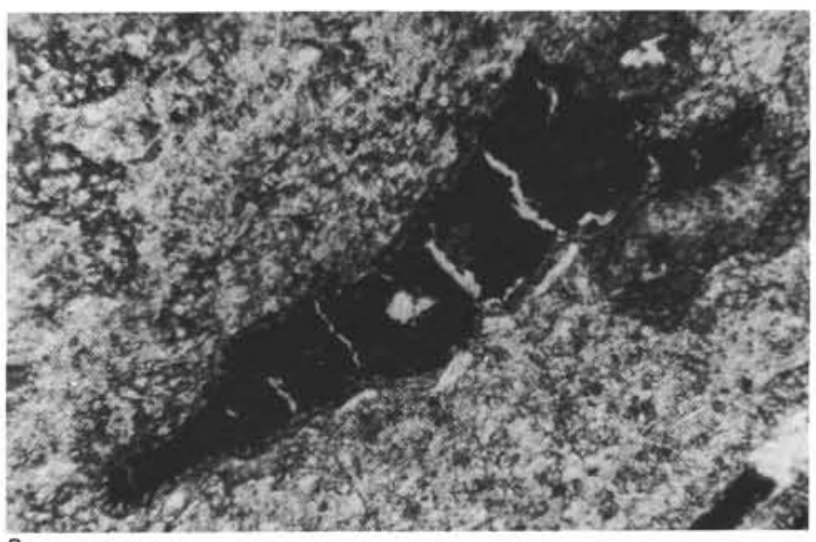

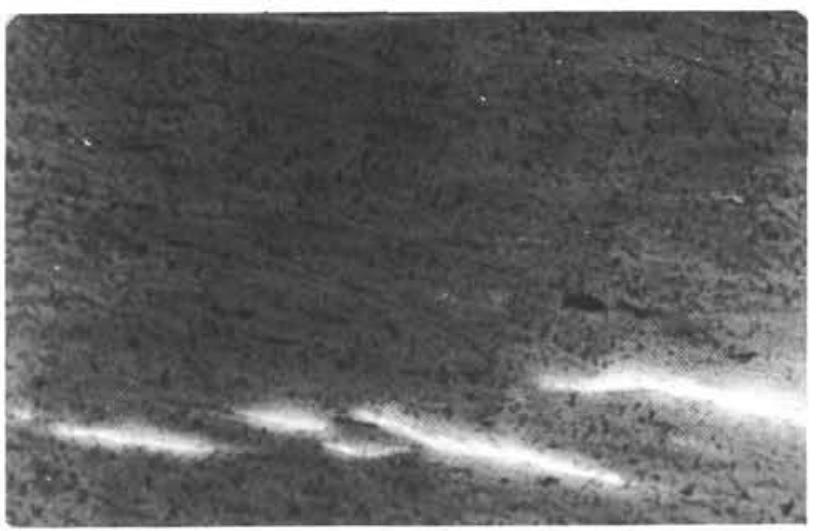

5 